$\xi=$

\title{
Comparative study on different types of photovoltaic modules under outdoor operating conditions in Minna, Nigeria
}

\author{
Ezenwora Joel Aghaegunam ${ }^{1 *}$, Oyedum David Onyedi², UgwuokePaulinusEkene $^{3}$ \\ ${ }^{1}$ Department of Physics, Federal University of Technology, P.M.B. 65 Minna, Nigeria \\ ${ }^{2}$ National Centre for Energy Research and Development, University of Nigeria, Nsukka \\ *Corresponding author E-mail:aghaegbunam@yahoo.com
}

\begin{abstract}
There is need to always obtain the realistic outdoor performance variables of Photovoltaic (PV) module in a location for efficient PV power system sizing and design. Outdoor performance evaluation was carried out on three types of commercially available silicon PV modules rated $10 \mathrm{~W}$ each, using CR1000 software-based Data Acquisition System (DAS). The PV modules under test and meteorological sensors were installed on a metal support structure at the same test plane.The data monitoring was from 08.00 to 18.00 hours each day continuously for a period of one year, from December 2014 to November 2015. Maximum values of module efficiencies of 5.86\% and $10.91 \%$ for the monocrystalline and polycrystalline modules were respectively recorded at irradiance of $375 \mathrm{~W} / \mathrm{m} 2$, while the amorphous efficiency peaked at $3.61 \%$ with irradiance of $536.5 \mathrm{~W} / \mathrm{m} 2$. At $1000 \mathrm{~W} / \mathrm{m} 2$ the efficiencies reduced to $3.30 \%, 6.20 \%$ and $2.25 \%$ as against manufacturer's specifications of $46 \%, 48 \%$ and $33 \%$ for the monocrystalline, polycrystalline and amorphous modules respectively. The maximum power output achieved for the modules at irradiance of $1000 \mathrm{~W} / \mathrm{m} 2$ were $0.711 \mathrm{~W}, 1.323 \mathrm{~W}$ and $0.652 \mathrm{~W}$ for the monocrystalline, polycrystalline and amorphous PV modules, respectively. Accordingly, Module Performance Ratios for the PV modules investigated were $0.07,0.13$ and 0.07 , respectively. The rate of variation of module response variables with irradiance and temperature was determined using a linear statistical model given as $\mathrm{Y}=\mathrm{a}+\mathrm{bHg}+\mathrm{c}$ Tmod. The approach performed creditably when compared with measured data.
\end{abstract}

Keywords: Amorphous; Module; Monocrystalline; Photovoltaic; Polycrystalline.

\section{Introduction}

The need to characterise and evaluate the performance of photovoltaic modules in order to ensure optimal performance and technical quality in photovoltaic power systems has been pointed out [1]. Standard Test Condition (STC) hardly occur outdoors, therefore the effect of deviation of meteorological parameters from STC together with the fact that PV modules with actual power smaller than the nominal value can still be found in the market lend credence to this. Essentially, PV power system design involves electrically-matching power components and ultimately, the power supply to the load. STC are easily recreated in a factory, and allow for consistent comparisons of products, but need to be modified to estimate output under common outdoor operating conditions. Module output power reduces as module temperature increases. The rate of decrease of output power with temperature for a particular locality ought to be understood and the loss factor for each module type in every location established. These loss factors need to be documented and applied in order to effectively estimate system output and sizing before installation. This will lead to the design and installation of efficient PV power system that is reliable, dependable and durable. In developed world such as the United States of America (USA) which is a lead actor in PV research, there have been efforts to conduct outdoor tests of modules and array performance since 1976 through the Sandia National Laboratory [2]. The US has effectively established and documented loss factors for all losses affecting PV power systems for all PV module types and for every location.
Realistic outdoor performance analysis of various types of modules is needed in developing countries such as Nigeria, in order to be able to effectively design and size arrays for different applications and sites. It is no longer news that Nigeria is an energy resource rich country, blessed with both fossil fuel reserves such as crude oil, natural gas, coal, and renewable energy resources like solar, wind, biomass, biogas and hydropower resources. It is also true that despite the abundance of these energy resources in Nigeria, the country is in short supply of electrical power. There is supply-demand gap particularly in view of the growing energy demand in the domestic, commercial and industrial sectors of the economy, and the reason for this is not farfetched. The National energy supply is at present almost entirely dependent on fossil fuels, firewood (which are depleting fast) and hydropower. The capacity utilisation of hydropower plants over the recent years has been reduced at about 30\% only [3]. According to Umar (1999), Grid power generation capacity in Nigeria as at 1990s was about $1,800 \mathrm{MW}$ or $31 \%$ of the installed capacity and according to Okafor and Joe-Uzuegbu (2010), less than $40 \%$ of the 150 million Nigerians in the country were supplied electricity from the national grid in the urban centres while in the rural centres, where about $70 \%$ of the population live, the availability of electricity dropped to $15 \%$ [4]. Nigeria with an annual population growth rate of about $2.8 \%$ (according to 2006 population census), the total Electricity generation capacity as at 2010 stood at less than $4000 \mathrm{MW}$ with per capita consumption of $0.03 \mathrm{~kW}$. With these figures, the level of shortage in Electricity supply becomes evident, resulting in consistent unreliability and epileptic nature of electricity supply in the country. While the initial capital investment may be higher, 
PV power system provides electrical power at less cost than electricity from generator, based on life-cycle cost. Because it has an added advantage of requiring little maintenance, low running costs and being environmentally friendly. PV power is the most reliable source of electricity ever invented and it is portable, easily installed, and virtually maintenance-free [5]. Therefore, this study was carried out with the-state-of-the-art DAS to determine the realistic outdoor performance of the three types of commercially available silicon PV module in Minna and its environs for effective design and sizing of $\mathrm{PV}$ power system.

\section{Materials and method}

\subsection{Monitoring stage}

The performance response of the silicon PV modules to ambient weather parameters; solar irradiance, temperature, wind speed and relative humidity, was monitored in Minna environment, using CR1000 software-based data logging system with computer interface. The PV modules under test, and meteorological sensors, were installed on support structure at the same test plane, at about three metres of height, so as to ensure adequate exposure to insolation and enough wind speed, since wind speed is proportional to height. The elevation equally ensures that the system is free from any shading from shrubs and also protected from damage or interference by intruders. Also, the whole experimental set up was secured in an area of about four metres in diameter. The modules were tilted at approximately $10^{\circ}$ (since Minna is on latitude $09^{\circ} 37^{\prime}$ $\mathrm{N})$ to horizontal and south-facing to ensure maximum insolation [6] [7]. The data monitoring was from $8.00 \mathrm{am}$ to $6.00 \mathrm{pm}$ local time, each day continuously for a period of one year, spanning from December 2014 to November 2015, so as to cover the two distinct and well defined climate seasons of the area. The experiment was carried out near Physics Department, Federal University of Technology, Minna (latitude 09 $37^{\prime} \mathrm{N}$, longitude $06^{\circ} 32^{\prime} \mathrm{E}$ and 249 metres above sea level). The sensors were connected directly to the CR1000 Campbell Scientific data logger, while the modules are connected to the logger via electronic loads. The logger was programmed to scan the load current from 0 to $1 \mathrm{~A}$ at intervals of $50 \mathrm{~mA}$ every 5 minutes, and average values of short-circuit current, $\mathrm{I}_{\mathrm{sc}}$, open-circuit voltage, $\mathrm{V}_{\mathrm{oc}}$, current at maximum power, $\mathrm{I}_{\max }$, voltage at maximum power, $\mathrm{V}_{\max }$, power and maximum power obtained from the modules together with the ambient parameters are recorded and logged.Data download at the data acquisition site was performed every 7 days to ensure effective and close monitoring of the DAS. At the end of each month and where necessary, hourly, daily and monthly averages of each of the parameters - solar irradiance, solar insolation, wind speed, ambient and module temperatures, and the output response variables (opencircuit voltage, $\mathrm{V}_{\mathrm{OC}}$, short-circuit current, IsC, voltage at maximum power, $\mathrm{V}_{\max }$, current at maximum power, Imax, efficiency, Eff and fill factor, FF) of the photovoltaic modules were obtained. The global solar radiation was monitored using Li-200SA M200 Pyranometer, manufactured by LI-COR Inc. USA, with calibration of 94.62 microamperes per $1000 \mathrm{~W} / \mathrm{m}^{2}$. The ambient temperature and relative humidity were monitored using HC2S3-L Rotronic HygroClip2 Temperature/Relative Humidity probe, manufactured in Switzerland. Wind speed was monitored using 03002-L RM Young Wind Sentry Set. And module temperature was monitored using 110PV-L Surface-Mount Temperature probe. All sensors were installed in the CR1000 Campbell Scientific data logger with measurement and control module. Plate I shows the data acquisition set up.

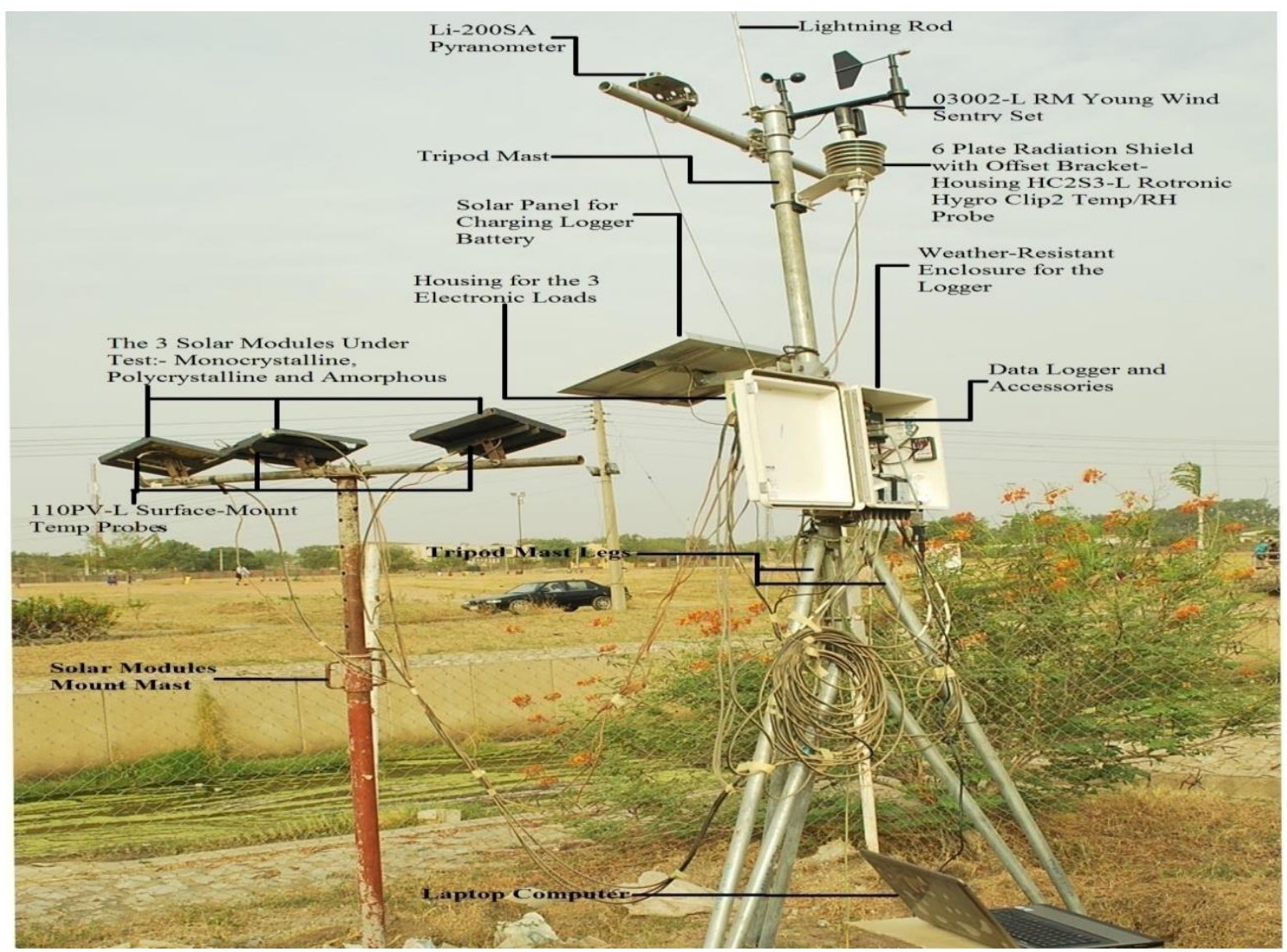

Plate 1: The Experimental Set Up (Near Physics Department, FUT Minna).

\subsection{Data analysis}

Performance responses for each of the modules type to ambient weather parameters was investigated in terms of open-circuit volt- age, $\mathrm{V}_{\mathrm{oc}}$, short-circuit current, $\mathrm{I}_{\mathrm{sc}}$, voltage at maximum power point, $\mathrm{V}_{\max }$, current at maximum power point, $\mathrm{I}_{\max }$, efficiency, Eff and fill factor, FF. Fill Factor, FF, Efficiency, Eff, and Module Performance Ratio (MPR) were evaluated using the following expressions: 
Fill Factor, $\mathrm{FF}=\mathrm{I}_{\max } \mathrm{V}_{\max } / \mathrm{I}_{\mathrm{sc}} \mathrm{V}_{\mathrm{oc}}$

Efficiency, Eff $=I_{\max } V_{\max } / P_{\text {in }}=I_{s c} V_{o c} F F / P_{\text {in }}=I_{s c} V_{o c} F F / A E_{e}$

Module Performance Ratio (MPR) = Effective Efficiency/Efficiency at STC

Statistical analysis was carried out with the aid of statistical package; Minitab 17 to determine the rate of variation of module response variables with irradiance and temperature, and linear statistical models for prediction of performance variables are presented Multiple regression models, analysis of variance (ANOVA) and correlation between the variables were considered with the aim of establishing the statistical significant relationship between the variables and the goodness of fit of the models for the research study. The regression equation is;

$\mathrm{Y}=\mathrm{a}+\mathrm{bH} \mathrm{g}+\mathrm{c} \mathrm{T}_{\mathrm{mod}}$

Where $\mathrm{Y}$ is the output response parameter being predicted, $\mathrm{H}_{\mathrm{g}}$ is global radiation (solar irradiance) and $\mathrm{T}_{\text {modis }}$ module temperature.The coefficients $\mathrm{b}$ and $\mathrm{c}$ are the rates of variation of output variables with respect to irradiance and module temperature, respectively while a is intercept on the $\mathrm{Y}$ axis.

The I-V curves were produced by plotting current against voltage produced by the logger in scanning the electronic load current from 0 to $1 \mathrm{~A}$ at intervals of $50 \mathrm{~mA}$. The maximum power point, $\mathrm{P}_{\max }$, which is the operating point of the module, was equally recorded by the logger.

\section{Results and discussion}

Figures 1 to 3 show the output characteristics of monocrystalline, polycrystalline and amorphous silicon PV modules respectively as functions of global irradiance. These output characteristics are expressed in the form of I-V curves.

However, the I-V characteristics of the amorphous module is worthy of note because it does not depict diode characteristics that is usually associated with solar modules. This is because the manufacturer's specifications are particularly too unrealistic that its actual performance is far below the range of the electronic load designed for it, which was based on the specifications of the manufacturer. Although it recorded the highest open-circuit voltage compared to the monocrystalline and polycrystalline, and its shortcircuit current is 0.62 amperes according to the manufacturer, but it could not deliver 0.05 amperes of current. This explains the sudden descent in the characteristic curve immediately it was loaded, giving slanting line instead of curve as seen in Figure 3. Generally, open-circuit voltage, $V_{o c}$, is seen to increase slowly with increase irradiance. Its increase is not commensurate with increase in irradiance and this explains the bunching of the I-V characteristics curves along voltage axis compared to relative regular spacing along the current axis. This is due to high temperature associated with increase in irradiance which is parasitic to open-circuit voltage and is more noticeable in monocrystalline and polycrystalline than in amorphous. On the contrast, the shortcircuit current increased generally with irradiance. This contrast in open-circuit voltage and short-circuit current is more glaring in Figures 4 to 9 where these performance variables are compared with module temperature at various irradiance levels.

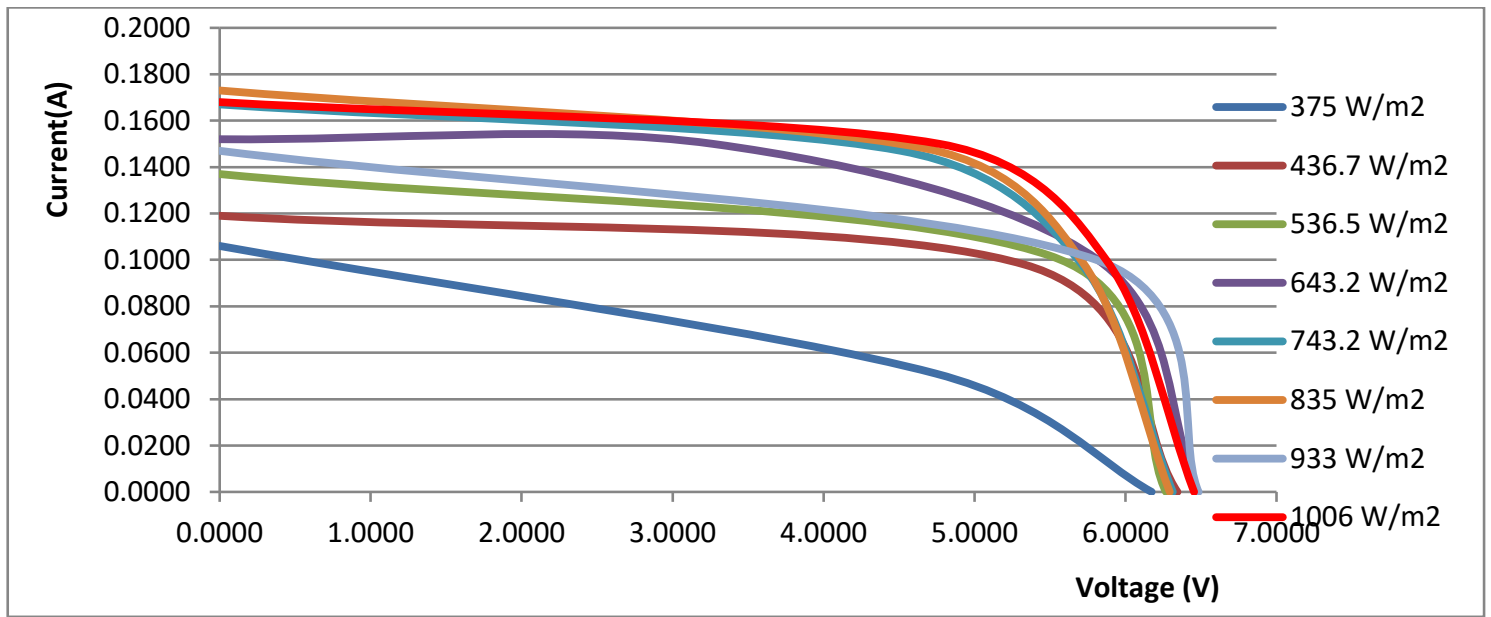

Fig. 1:I-V Characteristics for the Monocrystalline Silicon Module as A Function of Global Irradiance.

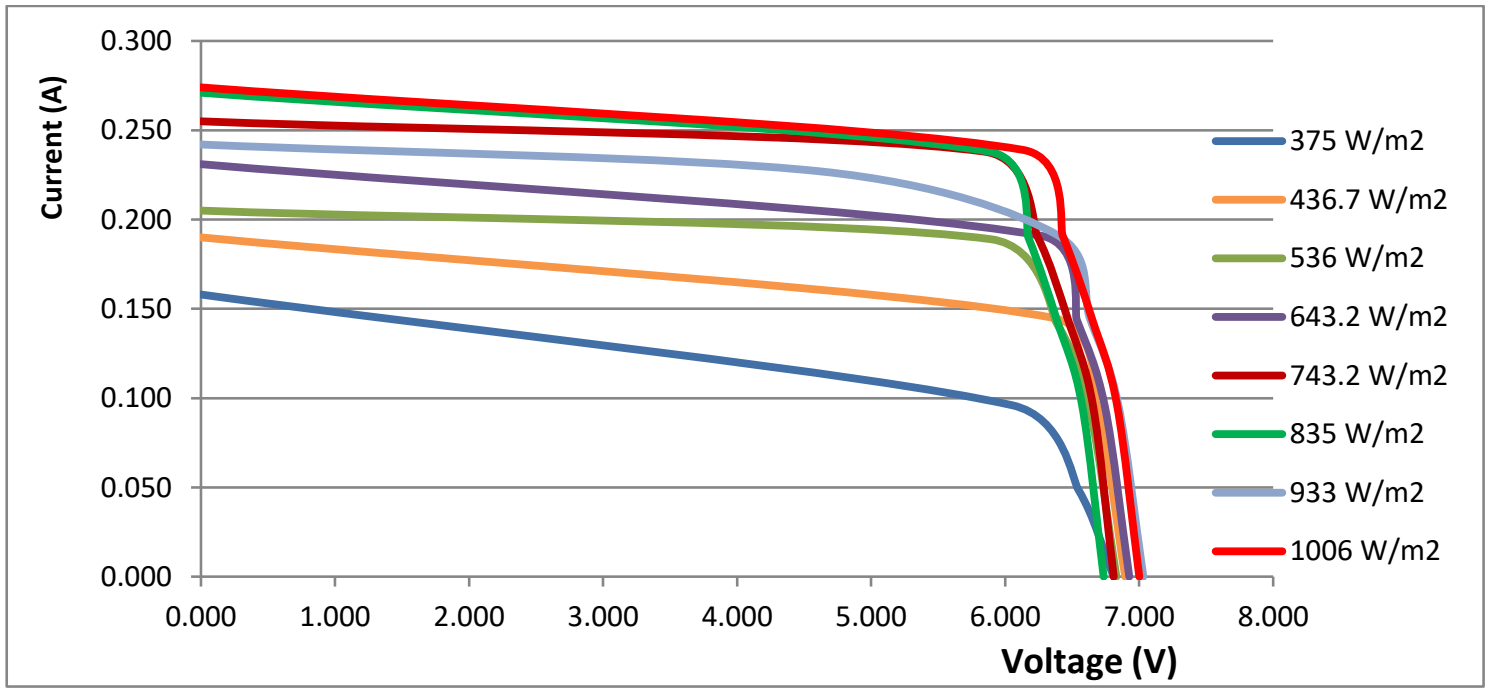

Fig. 2:I-V Characteristics for the Polycrystalline Silicon Module as A Function of Global Irradiance. 


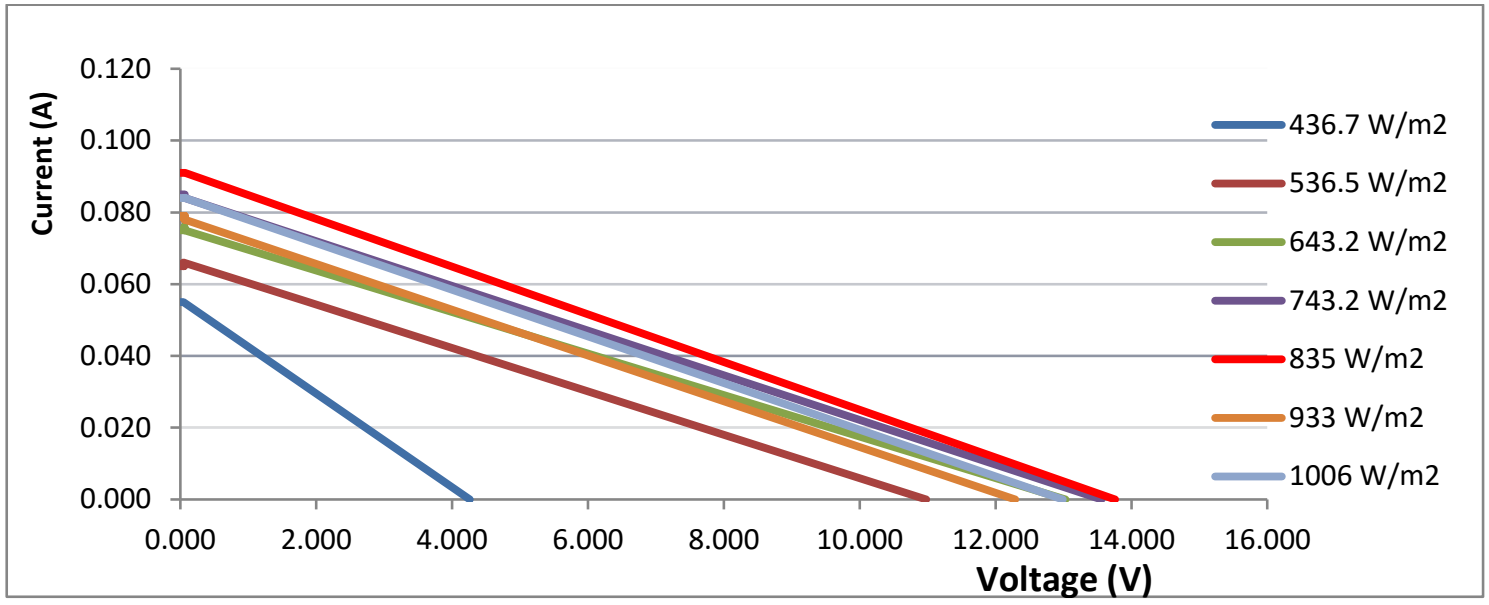

Fig. 3:I-V Characteristics for the Amorphous Silicon Module as A Function of Global Irradiance.

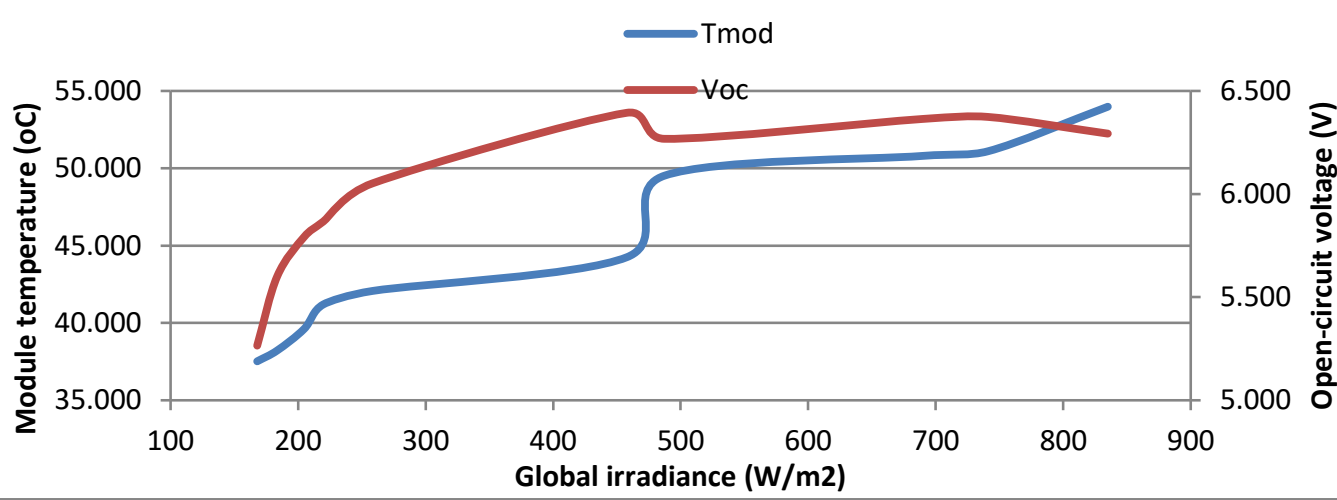

Fig. 4:Variation of Open-Circuit Voltage and Module Temperature as A Function of Global Irradiance for the Monocrystalline Module.

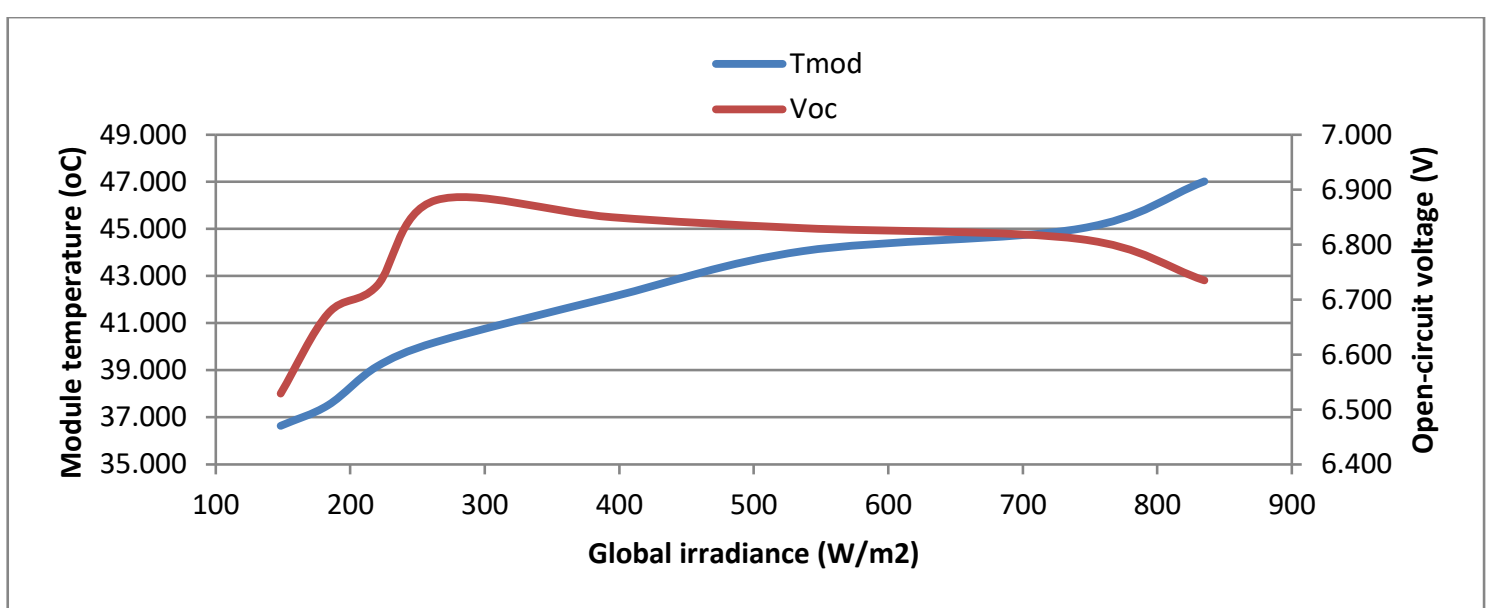

Fig. 5: Variation of Open-Circuit Voltage and Module Temperature as A Function of Global Irradiance for the Polycrystalline Module

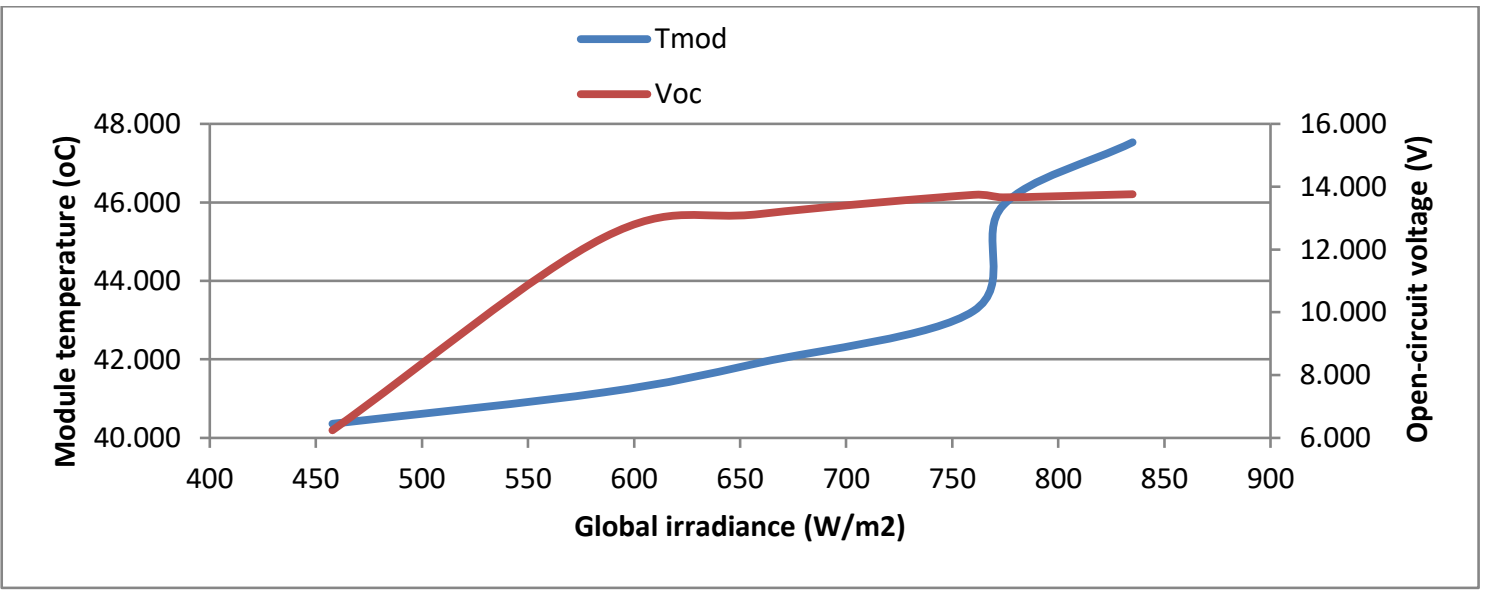

Fig. 6:Variation of Open-Circuit Voltage and Module Temperature as A Function of Global Irradiance for the Amorphous Module. 


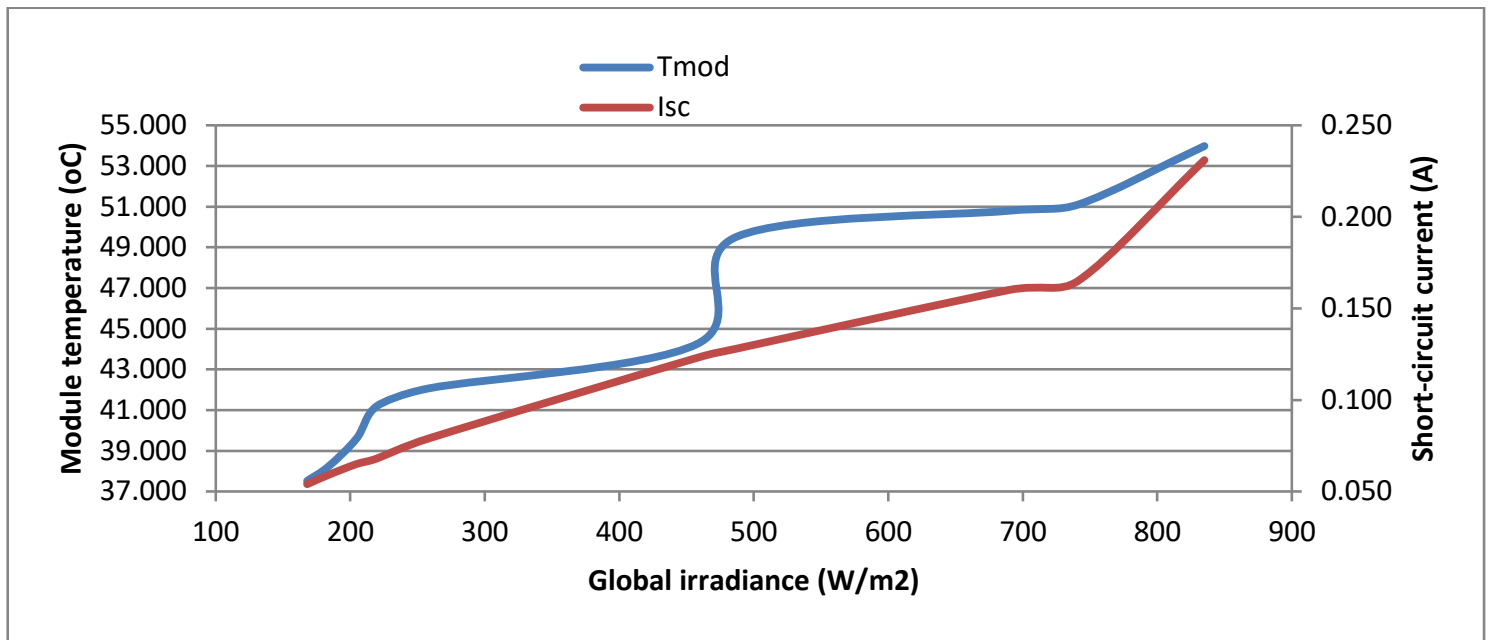

Fig. 7: Variation of Short-Circuit Current and Module Temperature as A Function of Global Irradiance for the Monocrystalline Module.

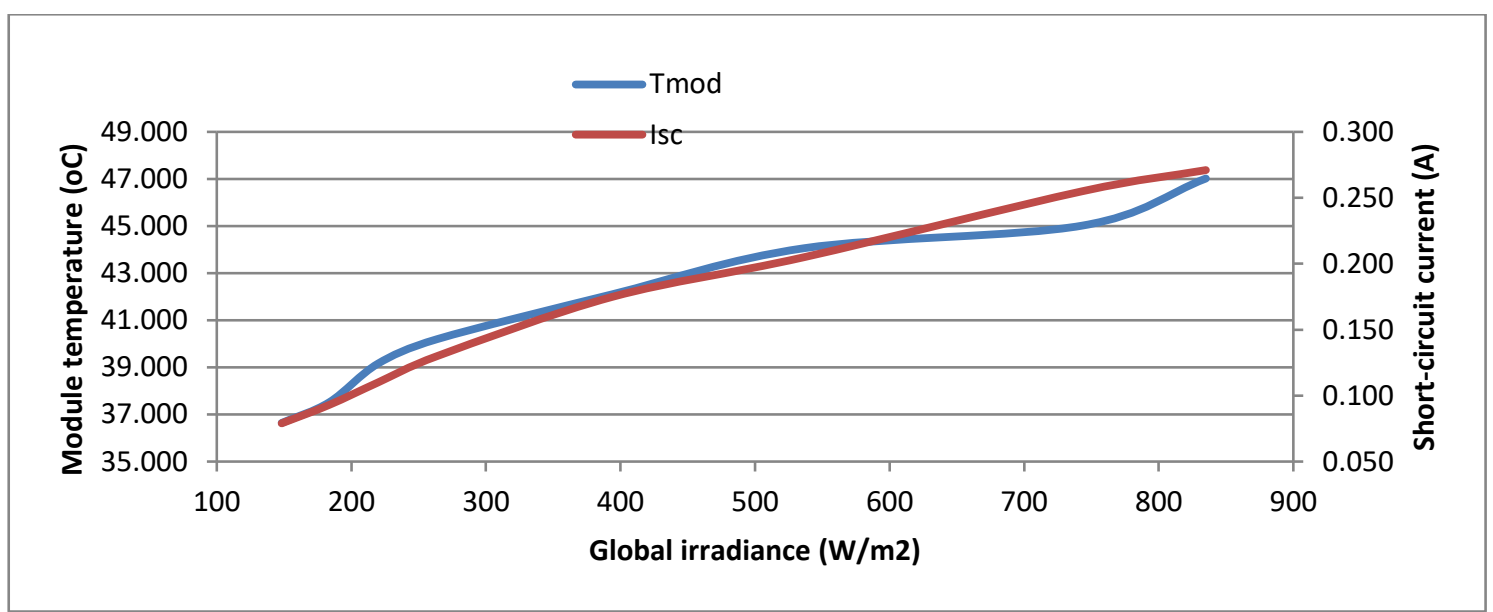

Fig. 8: Variation of Short-Circuit Current and Module Temperature as A Function of Global Irradiance for the Polycrystalline Module.

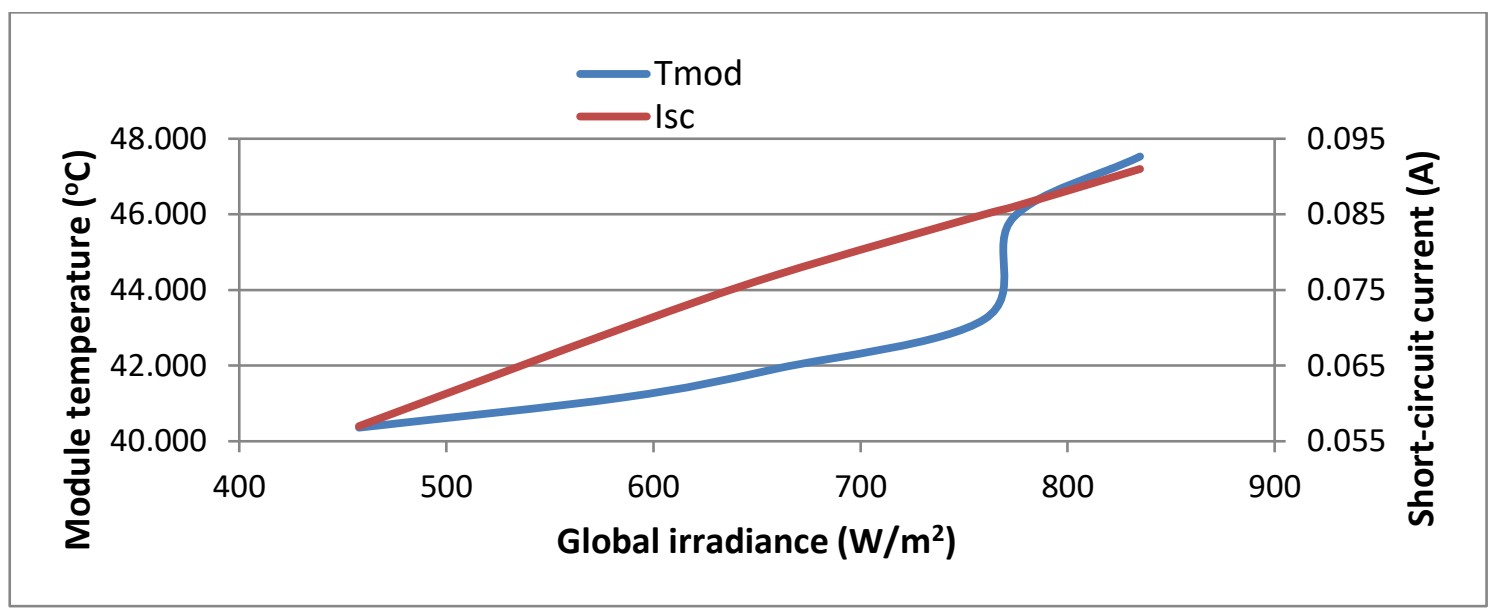

Fig. 9: Variation of Short-Circuit Current and Module Temperature as A Function of Global Irradiance for the Amorphous Module.

It can be observed that the three module types do not have uniform module temperature range, this is because they do not have uniform module architecture and so the position of the 110PV-L surface-mount temperature probes were at different levels of module back surface with the monocrystalline module having closest to the module substrate material and this explains why the monocrystalline module recorded the widest module temperature range. Generally speaking, it can be said that the short-circuit current for the three module types showed steady increase with increase in module temperature, at least for the range of solar irradiance measured but unlike the open-circuit voltage which decreased after attaining maximum value, mainly in the crystalline modules, the short-circuit current increased steadily. It is obvious then that the open-circuit voltage do not have linear relationship with mod- ule temperature and hence solar irradiance, as its plot is seen with a dip after attaining maximum value (in the crystalline modules), as against short-circuit current that increased steadily. Also this effect of temperature on open-circuit voltage is more significant in the monocrystalline and polycrystalline than in the amorphous silicon module, signifying that amorphous silicon is less affected by temperature variations. This result is in agreement with $\mathrm{Ug}$ wuoke and Okeke (2012) and other researchers in the field [8]. The relationship of maximum power point to temperature variations was investigated and shown in Figures 10 to 12 for the monocrystalline, polycrystalline and amorphous modules respectively. 


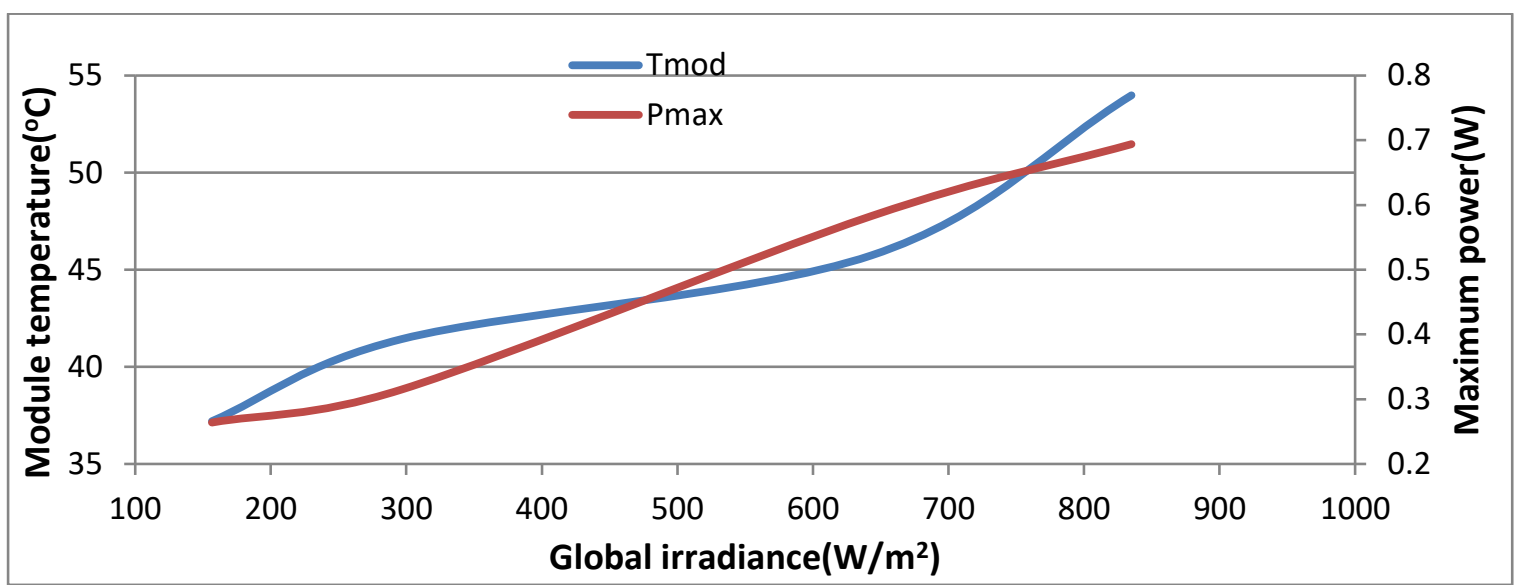

Fig. 10:Variation of Maximum Power Point (MPP) and Module Temperature at Different Levels of Irradiance for the Monocrystalline Module.

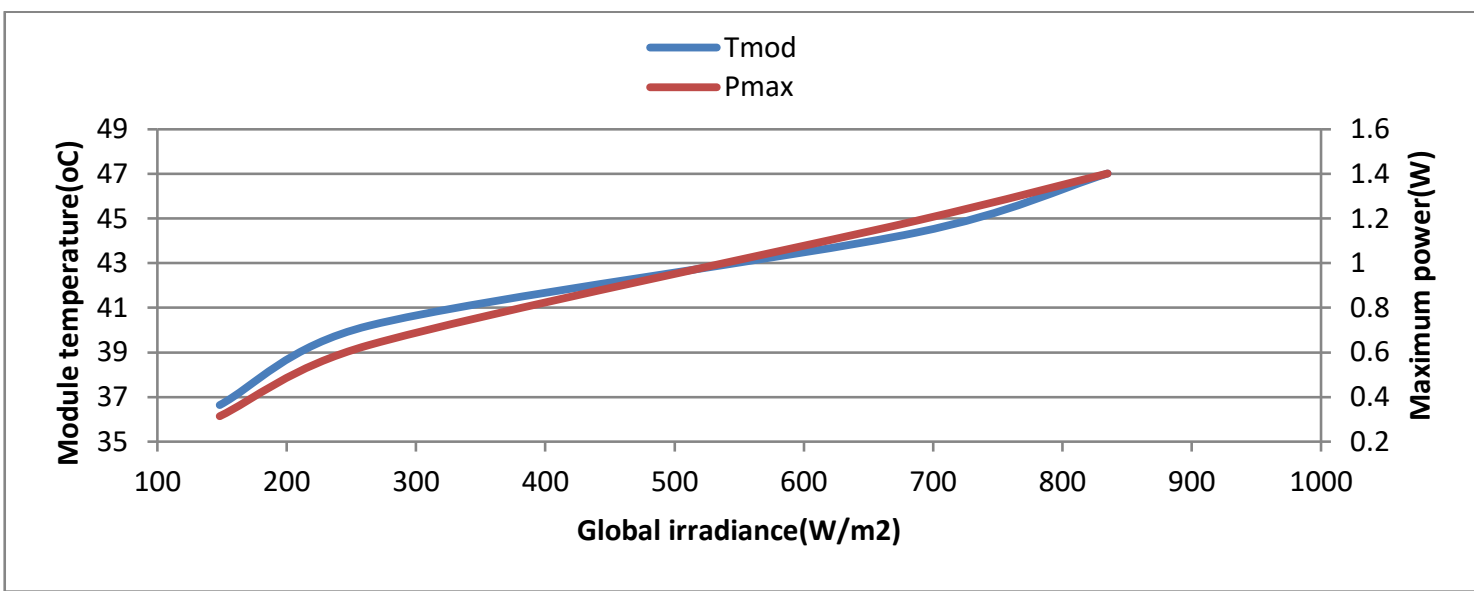

Fig. 11:Variation of Maximum Power Point (MPP) and Module Temperature at Different Levels of Irradiance for the Polycrystalline Module.

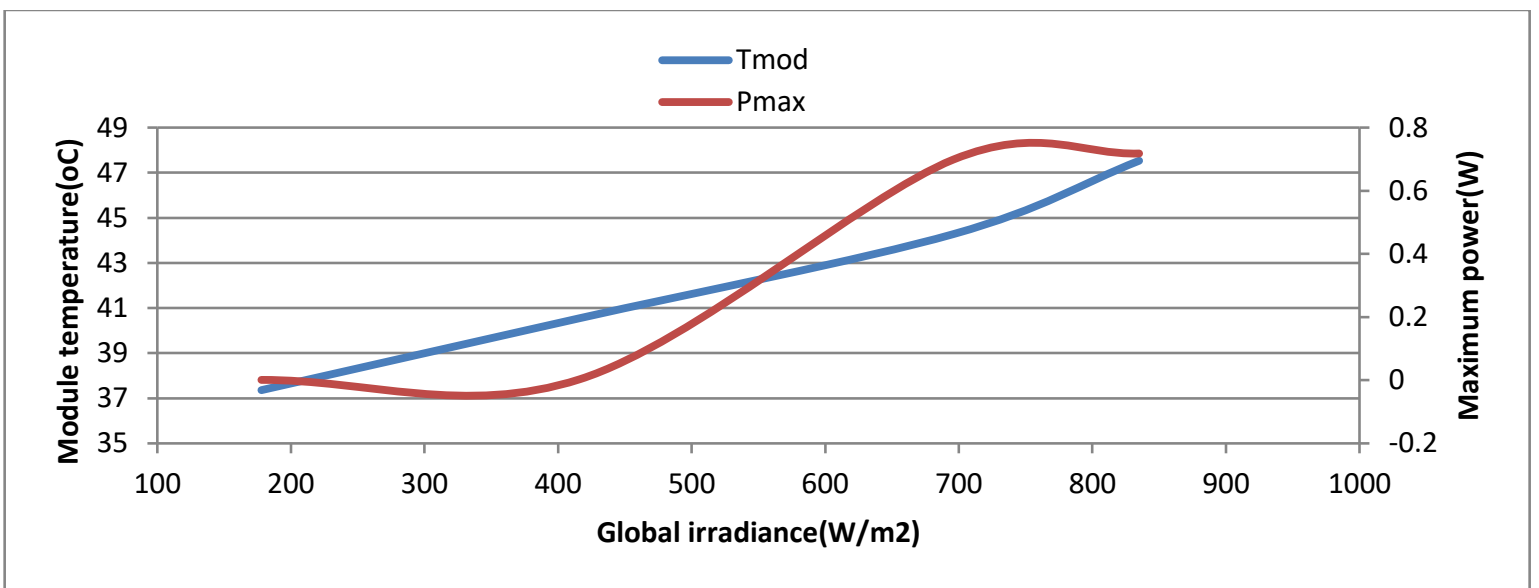

Fig. 12:Variation of Maximum Power Point (MPP) and Module Temperature at Different Levels of Irradiance for the Amorphous Module.

It was observed that the maximum power, like the short-circuit current, increased steadily with increased solar irradiance and module temperature for the monocrystalline and polycrystalline, suggesting that maximum power point is more correlated to current than voltage for the measured range of solar irradiance. While for the amorphous, maximum power is seen to be reluctant initially and thereafter increased rapidly between irradiance of 400 $\mathrm{W} / \mathrm{m}^{2}$ and $700 \mathrm{~W} / \mathrm{m}^{2}$ and again slows down between irradiance of $700 \mathrm{~W} / \mathrm{m}^{2}$ and $835 \mathrm{~W} / \mathrm{m}^{2}$, showing symmetrical structure at 550
$\mathrm{W} / \mathrm{m}^{2}$. As shown in these Figures the maximum power point increases with increase in solar irradiance and module temperature. This explains the inclusion of Maximum Power Point Tracker (MPPT) in some photovoltaic power system components.

Further dependence of module output parameters, like efficiency on global irradiance and module temperature was equally investigated and shown in Figures 13 to 15 for the three photovoltaic modules. 


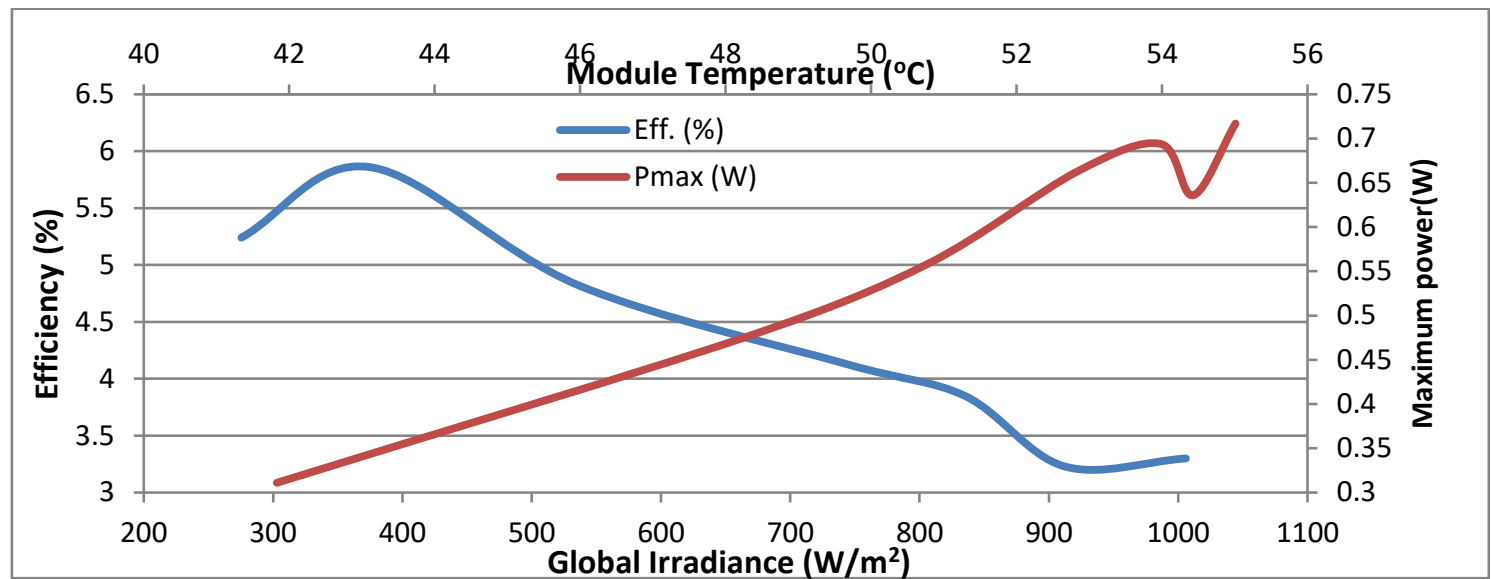

Fig. 13:Variation of Efficiency and Maximum Power Point as A Function of Global Irradiance and Module Temperature for the Monocrystalline Module.

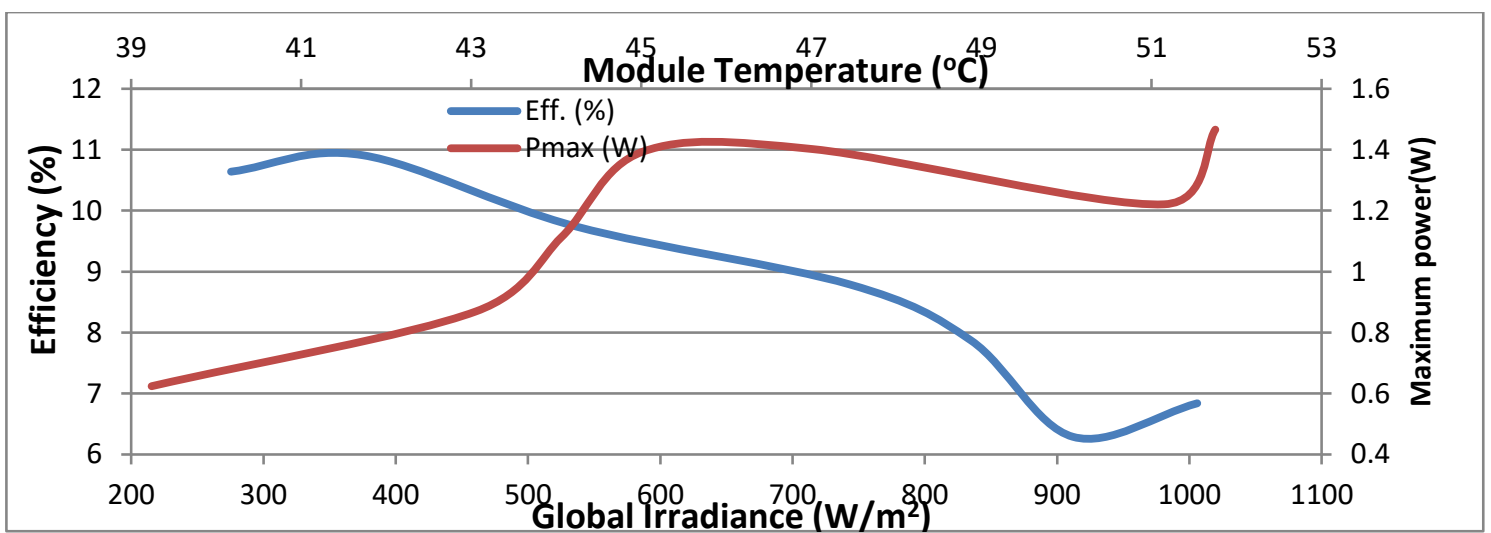

Fig. 14:Variation of Efficiency and Maximum Power Point as A Function of Global Irradiance and Module Temperature for the Polycrystalline Module.

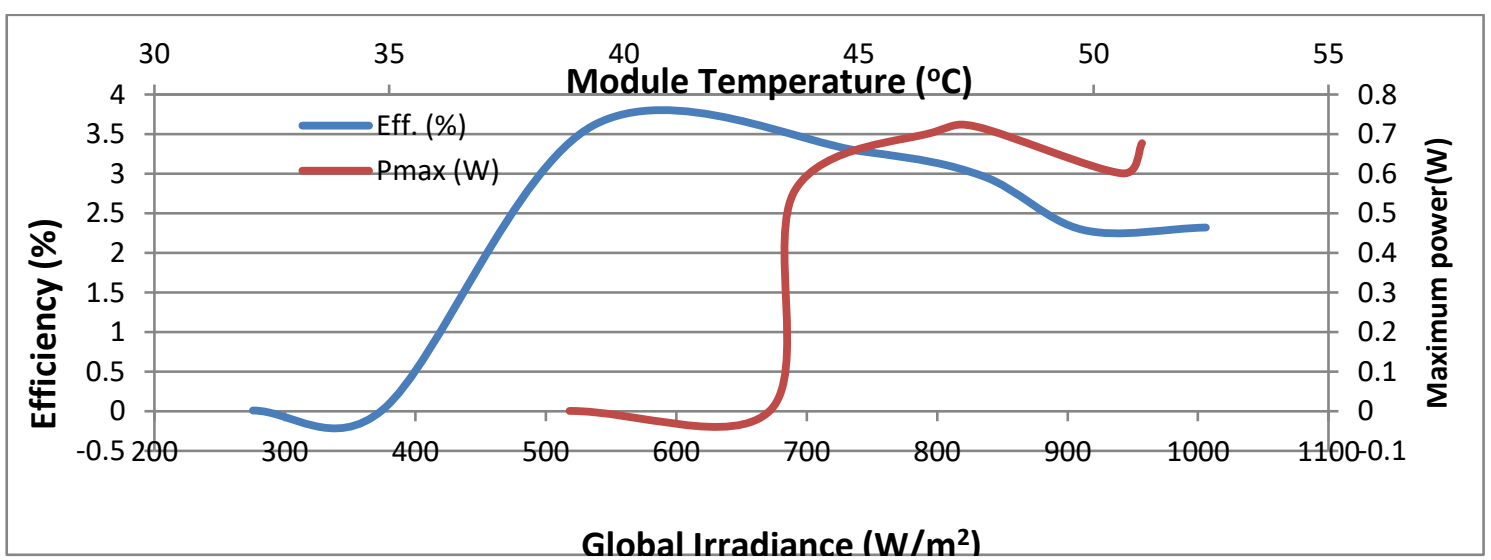

Fig. 15:Variation of Efficiency and Maximum Power Point as A Function of Global Irradiance and Module Temperature for the Amorphous Module.

It is seen that maximum power point curves still show slight linear relationship with solar irradiance and module temperature with an extended data plots, particularly for the monocrystalline module. Efficiency curves are approximately symmetrical at irradiance of about $600 \mathrm{~W} / \mathrm{m}^{2}$, particularly for the crystalline modules. This is in agreement with some earlier works [9] [10].
Monthly hourly averages of open-circuit voltage, short-circuit current, power output and maximum power are investigated and the plots for a typical dry season month (January) and a typical rainy season month (August) are shown in Figures 16 to 27. 


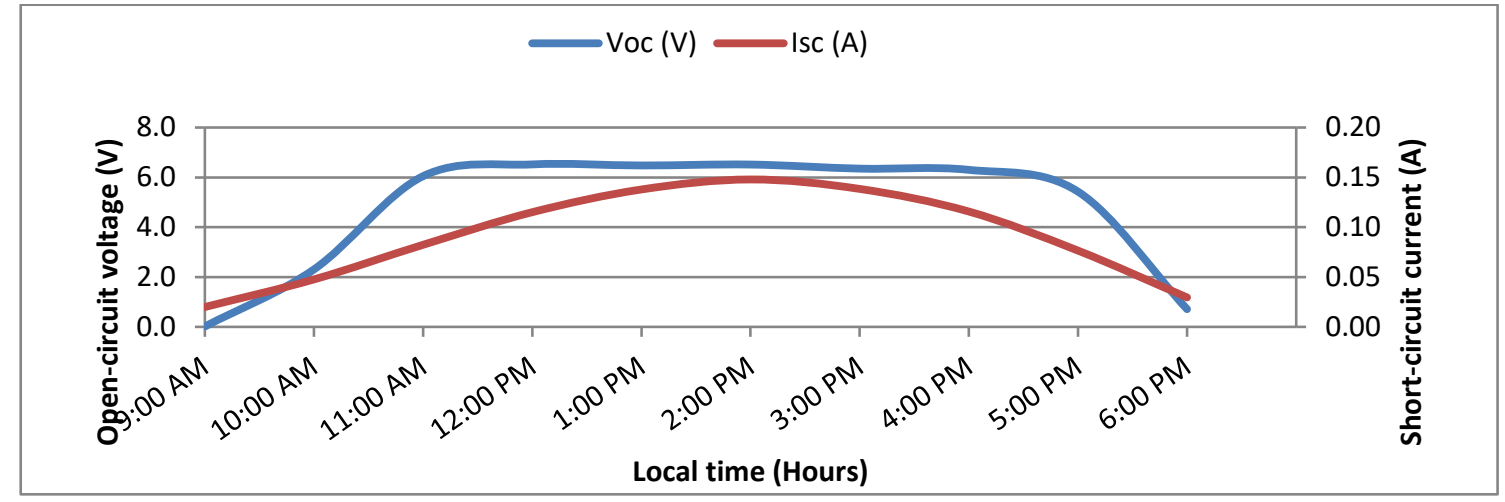

Fig. 16:Hourly Average Variation of Open-Circuit Voltage and Short-Circuit Current of Monocrystalline Silicon Module as A Function of Time for the Month of January 2015.

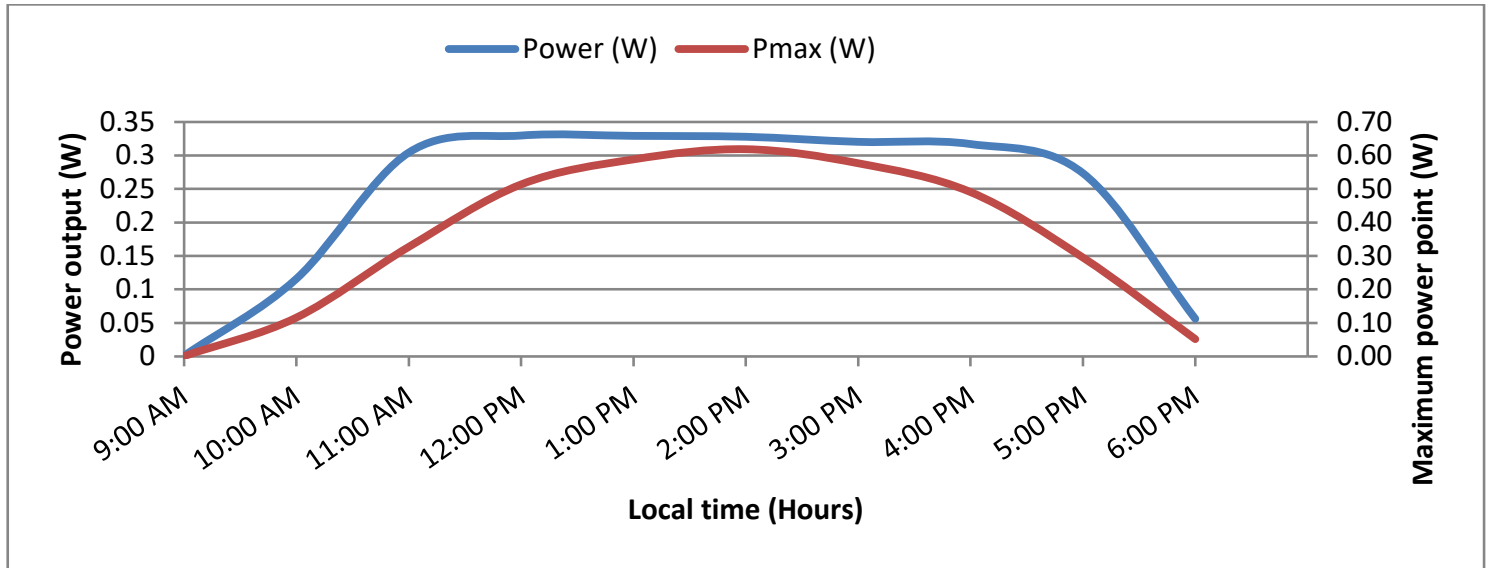

Fig. 17:Hourly Average Variation of Power and Maximum Power of Monocrystalline Silicon Module as A Function of Time for the Month of January 2015

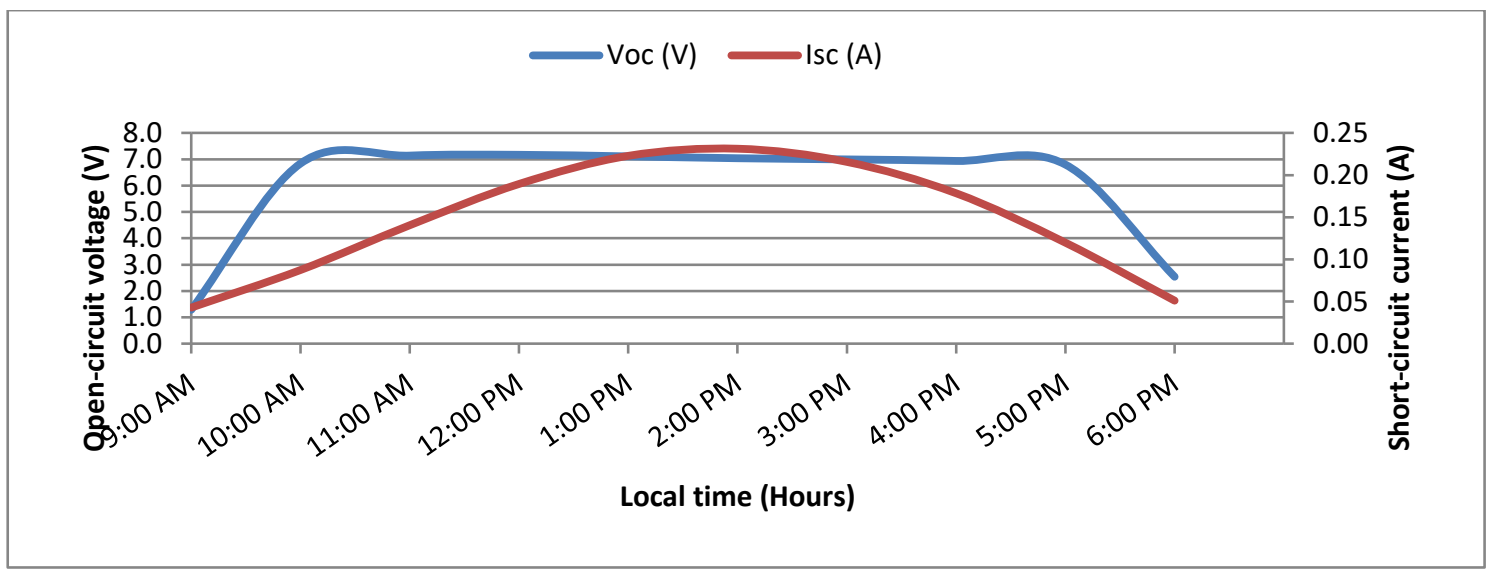

Fig. 18:Hourly Average Variation of Open-Circuit Voltage and Short-Circuit Current of Polycrystalline Silicon Module as A Function of Time for the Month of January 2015 .

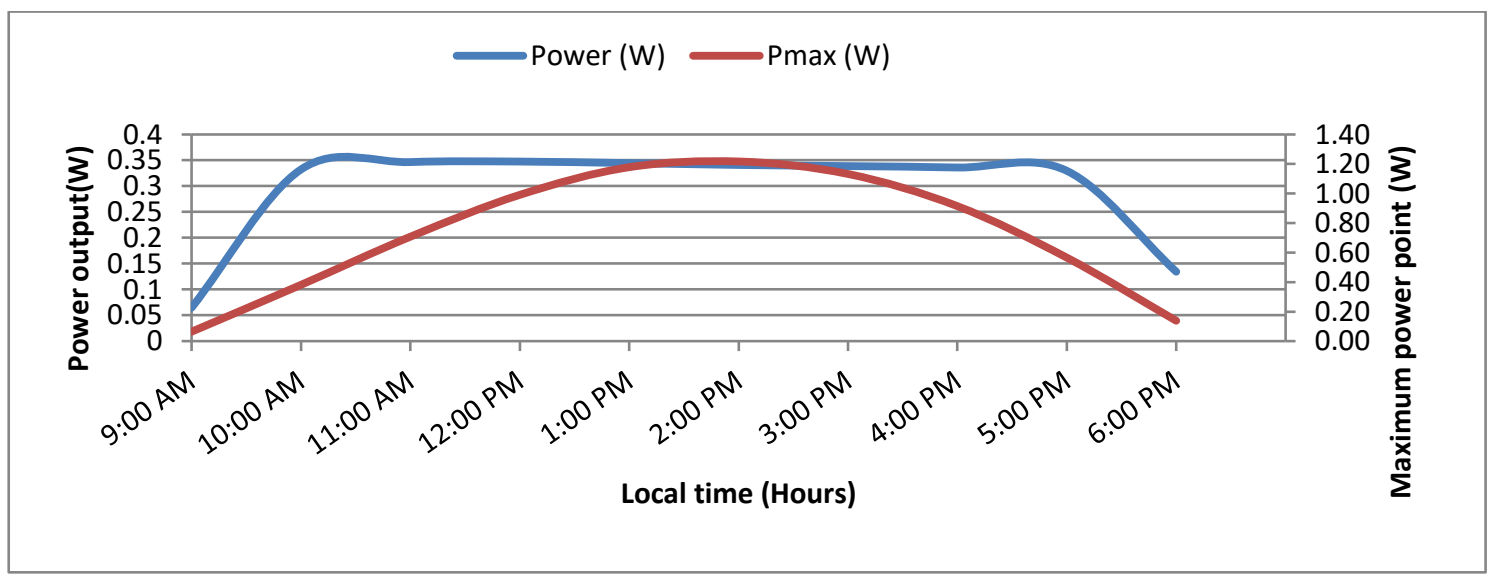

Fig. 19:Hourly Average Variation of Power and Maximum Power of Polycrystalline Silicon Module as A Function of Time for the Month of January 2015 


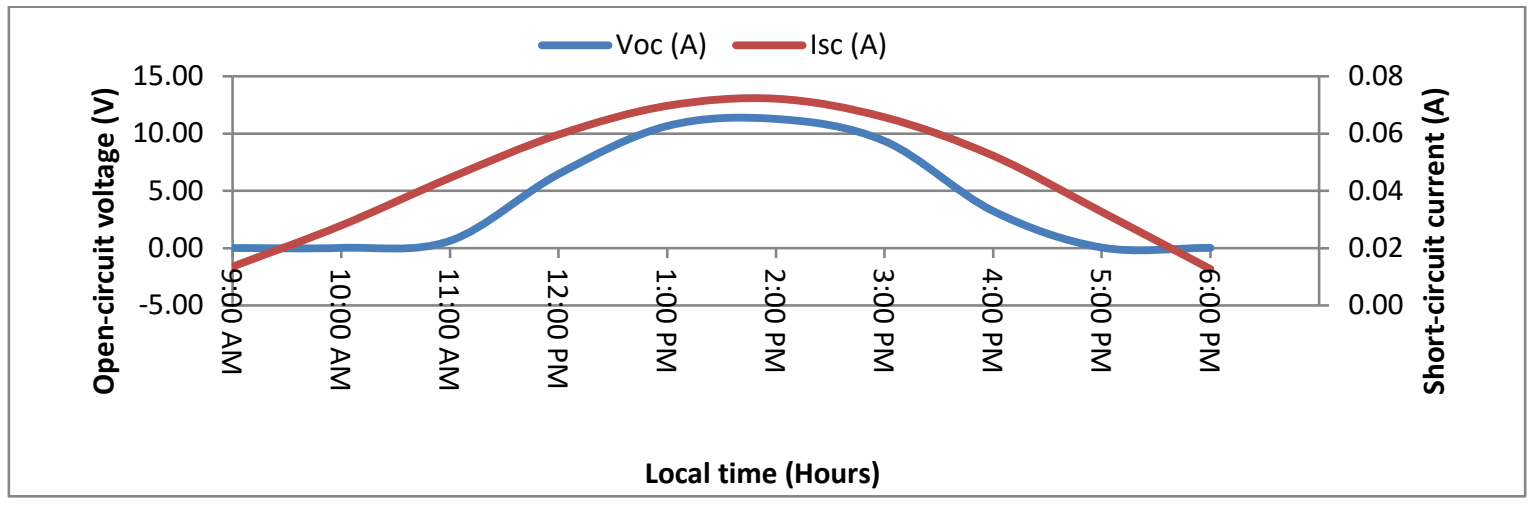

Fig. 20:Hourly Average Variation of Open-Circuit Voltage and Short-Circuit Current of Amorphous Silicon Module as A Function of Time for the Month of January 2015.

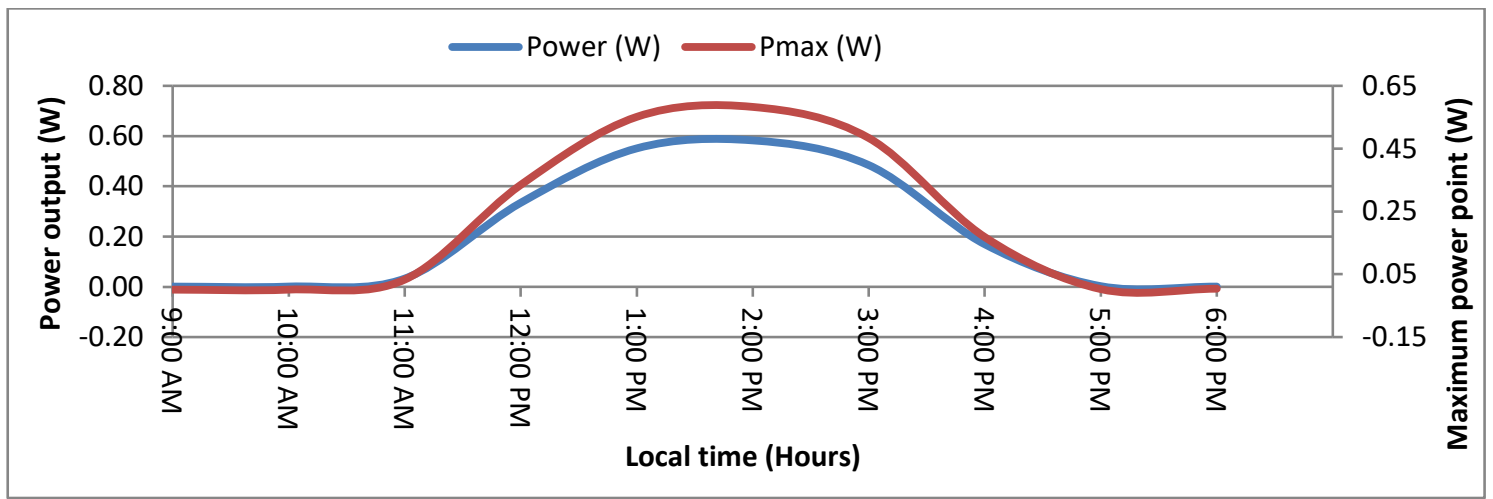

Fig. 21:Hourly Average Variation of Power and Maximum Power of Amorphous Silicon Module as A Function of Time for the Month of January 2015.

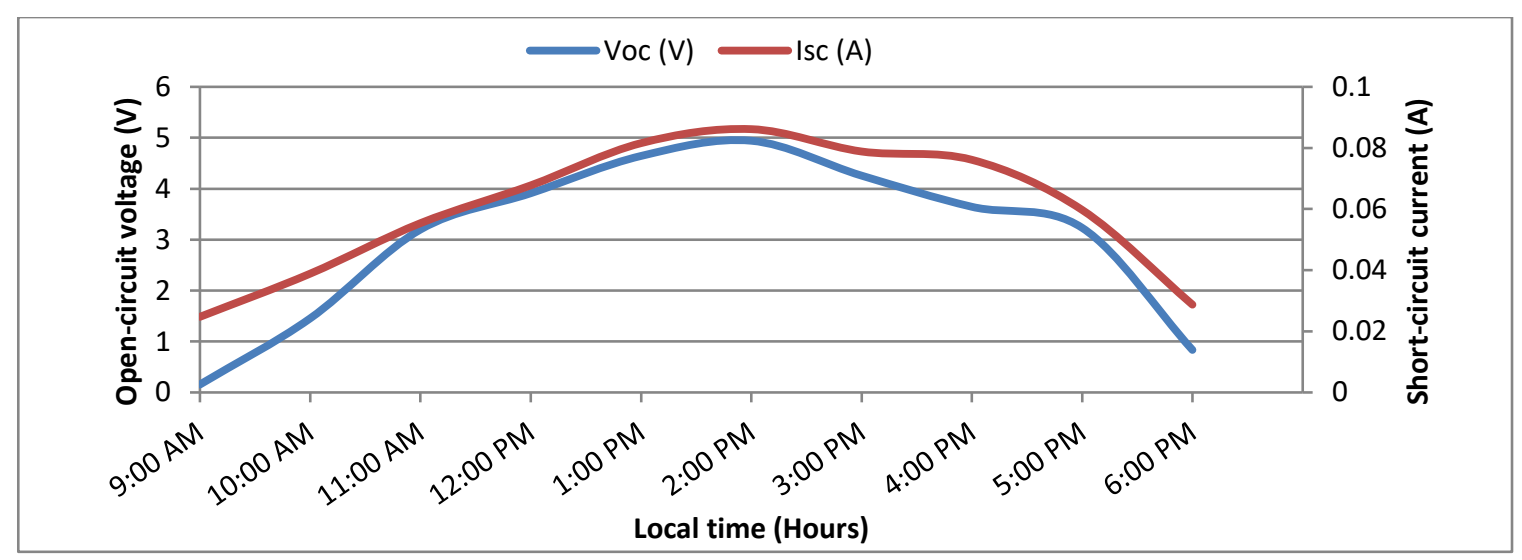

Fig. 22:Hourly Average Variation of Open-Circuit Voltage and Short-Circuit Current of Monocrystalline Silicon Module as A Function of Time for the Month of August 2015.

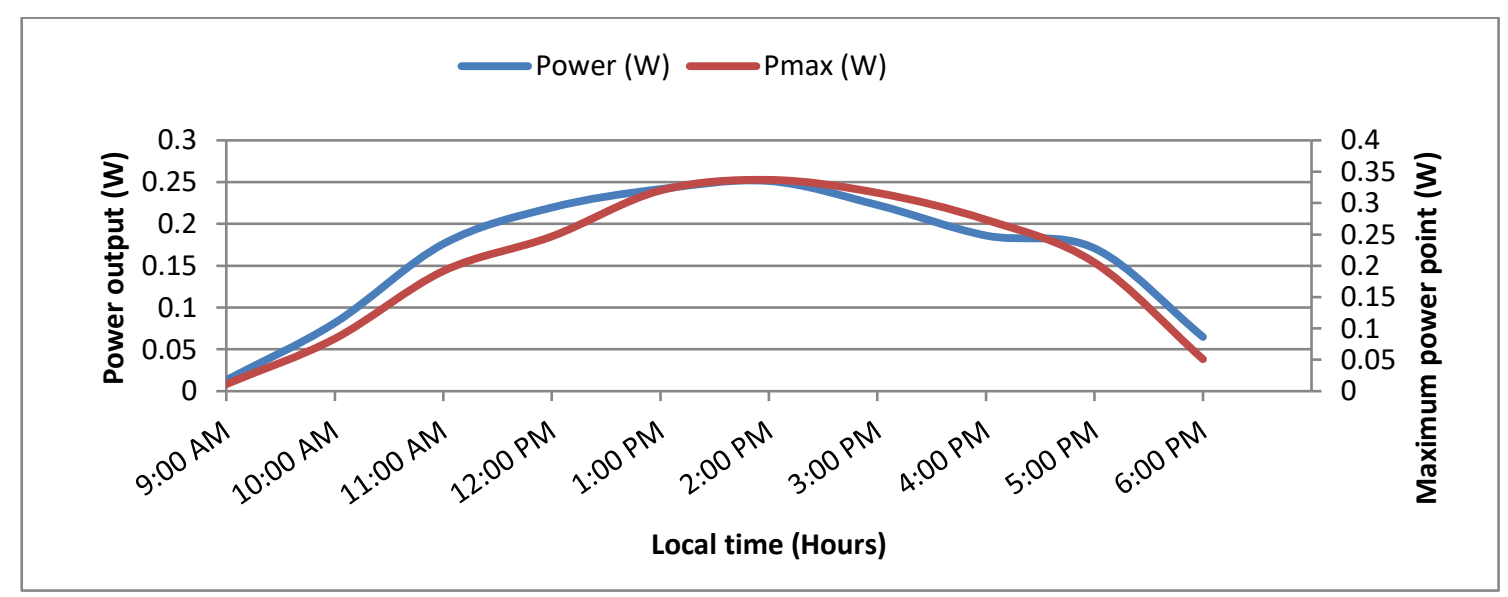

Fig. 23:Hourly Average Variation of Power and Maximum Power of Monocrystalline Silicon Module as A Function of Time for the Month of August 2015. 


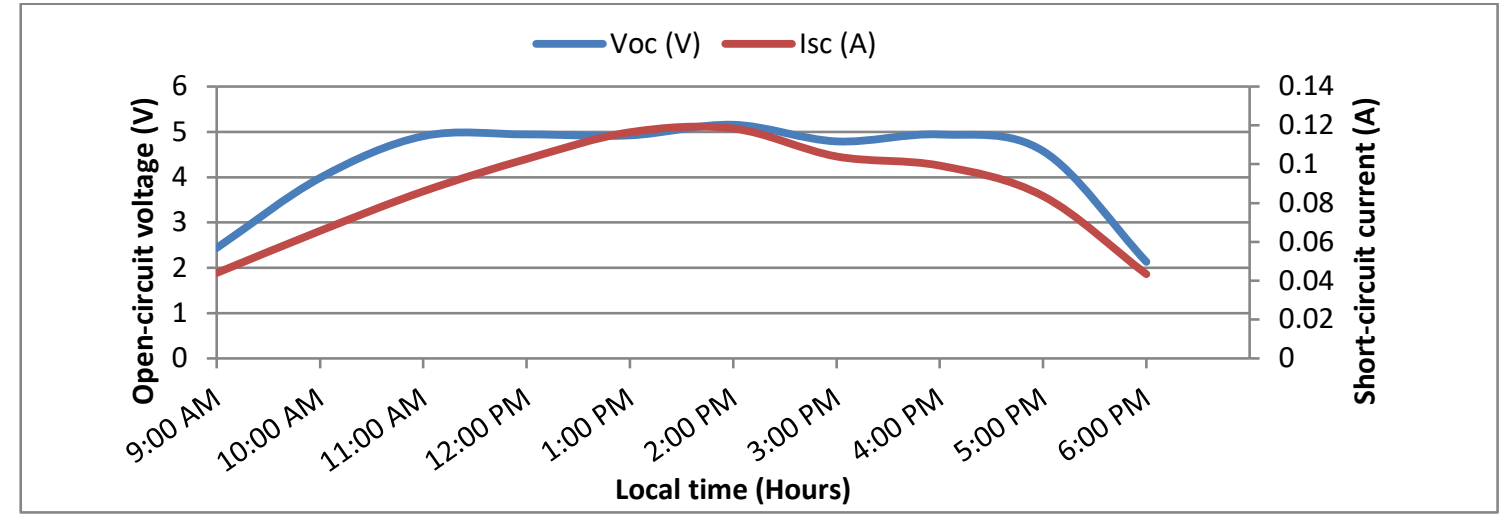

Fig. 24:Hourly Average Variation of Open-Circuit Voltage and Short-Circuit Current of Polycrystalline Silicon Module as A Function of Time for the Month ofAugust 2015.

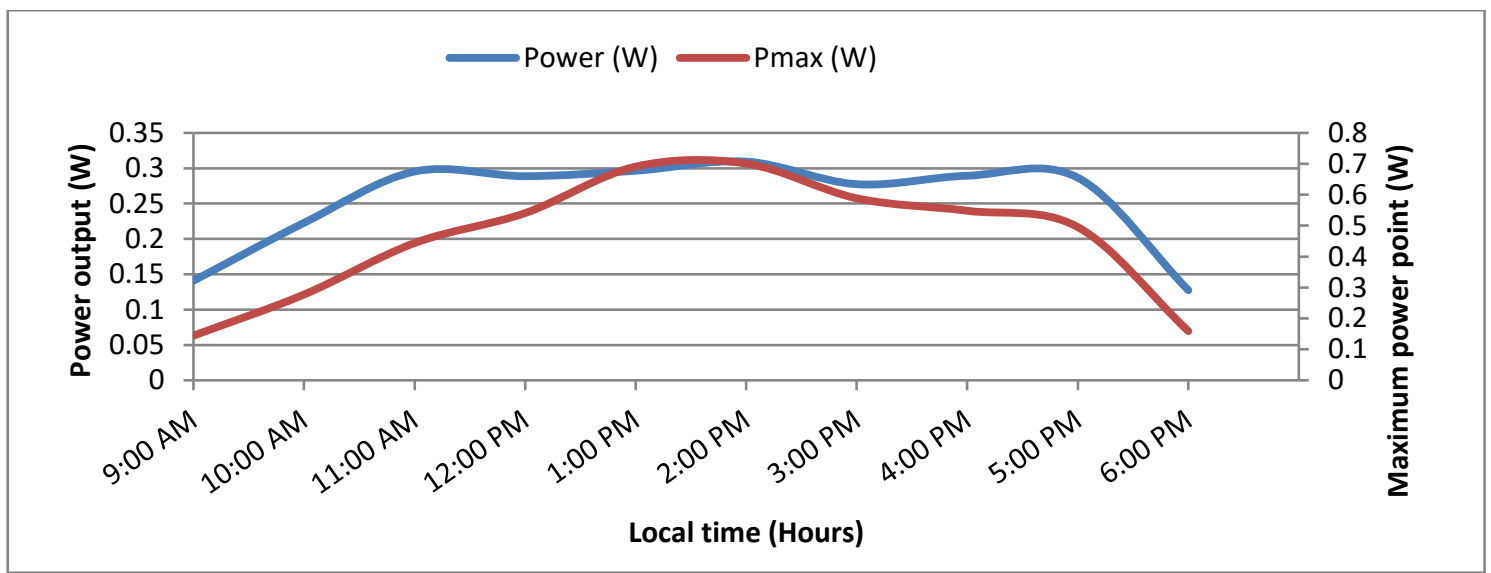

Fig. 25:Hourly Average Variation of Power and Maximum Power of Polycrystalline Silicon Module as A Function of Time for the Month of August 2015 .

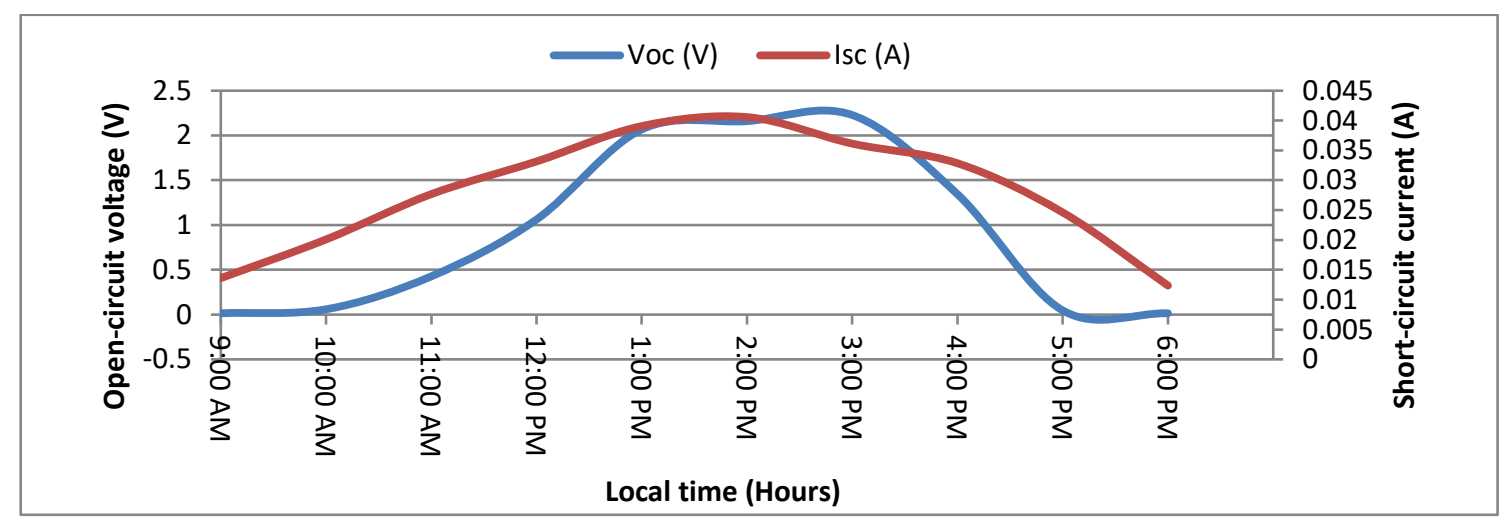

Fig. 26:Hourly Average Variation of Open-Circuit Voltage and Short-Circuit Current of Amorphous Silicon Module as A Function of Time for the Month of August 2015.

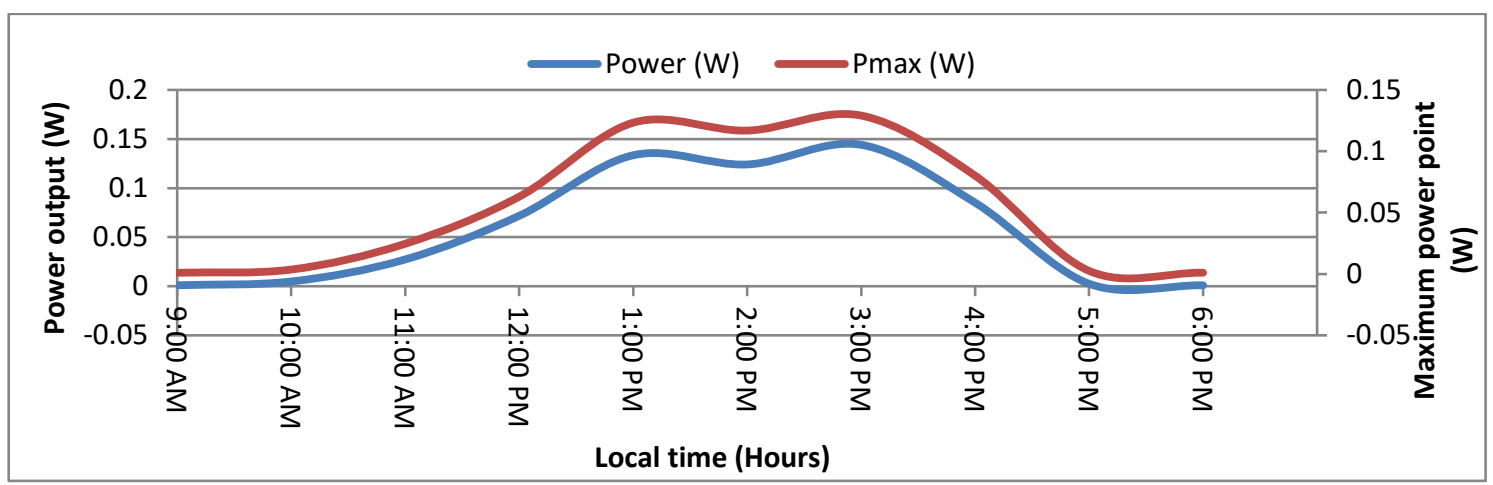

Fig. 27:Hourly Average Variation of Power and Maximum Power of Amorphous Silicon Module as A Function of Time for the Month of August 2015.

It was observed that open-circuit voltage peaks earlier in the day than short-circuit current for the monocrystalline and polycrystalline, while for the amorphous module, it is scarcely an exaggera- tion to say that all the performance variables peak in the afternoon time for all seasons. For the monocrystalline module the opencircuit voltage peaks at local noon time for the typical dry season 
month of January and then for the typical rainy season month of August, open-circuit voltage peaks at 2:00 pm local time. On the other hand the short-circuit current of the monocrystalline maintains a steady peak time of 2:00 pm local time for the two seasons. This is in the afternoon time when the module temperature is high, confirming that short-circuit current has a linear relationship with module temperature and solar irradiance. In the case of the polycrystalline module, the open-circuit voltage equally peaks at noon time for the month of January but for the rainy season month of August the peak time of open-circuit voltage shifts to 1:00 pm local time. The short-circuit current of the polycrystalline, like the monocrystalline, maintains its peak time at 2:00 pm local time. It is equally observed that power output peak time coincides with open-circuit voltage peak time and maximum power point peak time coincides with short-circuit current peak time for the monocrstalline and polycrystalline silicon modules, confirming earlier suggestion that current is more correlated to maximum power point than voltage and the well known fact that output voltage and power of crystalline silicon photovoltaic modules decreases at high temperatures as their module temperature increases. For the amorphous silicon module, as stated earlier, all the performance variables peak at the afternoon time for the two climatic seasons, at 2:00 pm and 3:00 pm local time, which is the peak time of module temperature for all the module types, again confirming that amorphous silicon module performance variables are less affected by high temperature. Its power output curves overlap with the maximum power curves, their scales are slightly made different in order for the two curves to be visible.

Hourly average values of the modules performance variables and ambient parameters for the one year duration of this study are shown in Tables $1-3$ for the monocrystalline, polycrystalline and amorphous silicon modules respectively.

Table 1: Annual Hourly Averages of Ambient Parameters and Performance Variables for the Monocrystalline Silicon Module

\begin{tabular}{llllllllll}
\hline $\mathrm{T}$ (Hours) & $\mathrm{H}_{\mathrm{g}}\left(\mathrm{W} / \mathrm{m}^{2}\right)$ & $\mathrm{T}_{\mathrm{a}}\left({ }^{\circ} \mathrm{C}\right)$ & $\mathrm{T}_{\bmod }\left({ }^{\circ} \mathrm{C}\right)$ & $\mathrm{V}_{\mathrm{oc}}(\mathrm{V})$ & $\mathrm{I}_{\mathrm{sc}}(\mathrm{A})$ & Power $(\mathrm{W})$ & $\mathrm{P}_{\max }(\mathrm{W})$ & $\mathrm{RH}(\%)$ & $\mathrm{WS}(\mathrm{m} / \mathrm{s})$ \\
\hline 9:00 AM & 258 & 26.5 & 28.2 & 0.58 & 0.030 & 0.032 & 0.031 & 65.3 & 1.99 \\
10:00 AM & 427 & 27.8 & 32.2 & 3.13 & 0.057 & 0.163 & 0.176 & 61.8 & 2.18 \\
11:00 AM & 569 & 29.1 & 36.1 & 5.27 & 0.085 & 0.269 & 0.330 & 54.5 & 2.17 \\
12:00 PM & 666 & 30.3 & 39.6 & 5.69 & 0.109 & 0.289 & 0.443 & 53.2 & 2.08 \\
1:00 PM & 708 & 31.3 & 42.3 & 5.90 & 0.124 & 0.299 & 0.502 & 51.5 & 2.02 \\
2:00 PM & 696 & 32.2 & 43.9 & 5.95 & 0.130 & 0.301 & 0.521 & 48.8 & 1.93 \\
3:00 PM & 608 & 32.7 & 43.5 & 5.67 & 0.120 & 0.290 & 0.484 & 47.3 & 1.87 \\
4:00 PM & 482 & 33.0 & 42.1 & 5.41 & 0.101 & 0.276 & 0.408 & 45.7 & 1.82 \\
5:00 PM & 309 & 32.9 & 38.9 & 4.33 & 0.068 & 0.224 & 0.246 & 44.9 & 1.71 \\
6:00 PM & 139 & 31.9 & 33.8 & 0.80 & 0.030 & 0.057 & 0.053 & 46.2 & 1.59 \\
\hline
\end{tabular}

Table 2: Annual Hourly Averages of Ambient Parameters and Performance Variables for the Polycrystalline Silicon Module

\begin{tabular}{|c|c|c|c|c|c|c|c|c|c|}
\hline $\mathrm{T}$ (Hours) & $\mathrm{H}_{\mathrm{g}}\left(\mathrm{W} / \mathrm{m}^{2}\right)$ & $\mathrm{T}_{\mathrm{a}}\left({ }^{\circ} \mathrm{C}\right)$ & $\mathrm{T}_{\bmod }\left({ }^{\circ} \mathrm{C}\right)$ & $\mathrm{V}_{\mathrm{oc}}(\mathrm{V})$ & $\mathrm{I}_{\mathrm{sc}}(\mathrm{A})$ & Power (W) & $\mathrm{P}_{\max }(\mathrm{W})$ & RH (\%) & $\mathrm{WS}(\mathrm{m} / \mathrm{s})$ \\
\hline 9:00 AM & 258 & 26.5 & 27.6 & 3.30 & 0.056 & 0.169 & 0.186 & 65.3 & 1.99 \\
\hline 10:00 AM & 427 & 27.8 & 30.6 & 6.12 & 0.099 & 0.306 & 0.461 & 61.8 & 2.18 \\
\hline 11:00 AM & 569 & 29.1 & 33.5 & 6.52 & 0.143 & 0.324 & 0.724 & 54.5 & 2.17 \\
\hline 12:00 PM & 666 & 30.3 & 36.3 & 6.61 & 0.178 & 0.327 & 0.920 & 53.2 & 2.08 \\
\hline 1:00 PM & 708 & 31.3 & 38.4 & 6.66 & 0.202 & 0.331 & 1.064 & 51.5 & 2.02 \\
\hline 2:00 PM & 696 & 32.2 & 39.9 & 6.62 & 0.208 & 0.330 & 1.089 & 48.8 & 1.93 \\
\hline 3:00 PM & 608 & 32.7 & 40.0 & 6.46 & 0.190 & 0.324 & 0.990 & 47.3 & 1.87 \\
\hline 4:00 PM & 482 & 33.0 & 39.3 & 6.43 & 0.161 & 0.321 & 0.827 & 45.7 & 1.82 \\
\hline 6:00 PM & 139 & 31.9 & 33.8 & 2.83 & 0.052 & 0.154 & 0.170 & 46.2 & 1.59 \\
\hline
\end{tabular}

Table 3: Annual Hourly Averages of Ambient Parameters and Performance Variables for the Amorphous Silicon Module

\begin{tabular}{llllllllll}
\hline $\mathrm{T}$ (Hours) & $\mathrm{H}_{\mathrm{g}}\left(\mathrm{W} / \mathrm{m}^{2}\right)$ & $\mathrm{T}_{\mathrm{a}}\left({ }^{\circ} \mathrm{C}\right)$ & $\mathrm{T}_{\bmod }\left({ }^{\circ} \mathrm{C}\right)$ & $\mathrm{V}_{\mathrm{oc}}(\mathrm{V})$ & $\mathrm{I}_{\mathrm{sc}}(\mathrm{A})$ & Power $(\mathrm{W})$ & $\mathrm{P}_{\max }(\mathrm{W})$ & $\mathrm{RH}(\%)$ & $\mathrm{WS}(\mathrm{m} / \mathrm{s})$ \\
\hline 9:00 AM & 258 & 26.5 & 27.4 & 0.02 & 0.017 & 0.001 & 0.001 & 65.3 & 1.99 \\
10:00 AM & 427 & 27.8 & 30.3 & 0.42 & 0.030 & 0.023 & 0.023 & 61.8 & 2.18 \\
11:00 AM & 569 & 29.1 & 32.9 & 2.11 & 0.043 & 0.113 & 0.112 & 54.5 & 2.17 \\
12:00 PM & 666 & 30.3 & 35.4 & 5.02 & 0.054 & 0.264 & 0.262 & 53.2 & 2.08 \\
1:00 PM & 708 & 31.3 & 37.3 & 6.99 & 0.060 & 0.366 & 0.364 & 51.5 & 2.02 \\
2:00 PM & 696 & 32.2 & 38.5 & 7.29 & 0.061 & 0.382 & 0.379 & 48.8 & 1.93 \\
3:00 PM & 608 & 32.7 & 38.6 & 5.89 & 0.054 & 0.316 & 0.313 & 47.3 & 1.87 \\
4:00 PM & 482 & 33.0 & 38.0 & 1.99 & 0.044 & 0.112 & 0.109 & 45.7 & 1.82 \\
5:00 PM & 309 & 32.9 & 36.4 & 0.06 & 0.028 & 0.003 & 0.003 & 44.9 & 1.71 \\
6:00 PM & 139 & 31.9 & 33.2 & 0.02 & 0.013 & 0.001 & 0.002 & 46.2 & 1.59 \\
\hline
\end{tabular}

For the monocrystalline and amorphous modules, all their performance variables are seen to peak at 2:00 pm local time while the polycrystalline module maintains the trend it has for the hourly monthly averages; its open-circuit voltage peaks earlier in the day than the short-circuit current with the power output and maximum power point tracking the open-circuit voltage and short-circuit current profiles respectively. For the ambient parameters, solar irradiance (global radiation) peak time is at $1: 00 \mathrm{pm}$, ambient temperature $(\mathrm{Ta})$ is at 5:00 pm, wind speed is at 10:00 am and relative humidity is at 9:00 am local time.

The monthly average values of solar irradiance, wind speed and relative humidity together with open-circuit voltage, short-circuit current, maximum power and module temperature for the three module types are presented in Table 4 .

It was observed here that wind speed peaked in the month of January, during the dry season of the study area, normally characterised by strong North-East trade wind and favours open-circuit voltage more than short-circuit current (amidst other factors) for the three module types. Also it is observed that module temperature recorded relatively low value, vis-a-vis their irradiance levels, for the three modules during this month. This is because high wind speed leads to increased rate of heat transfer from the modules to the ambient resulting in the low module temperature that favours open-circuit voltage more than short-circuit current. Relative humidity peaked in the month of August, which is the peak of rainy season of the study area and leads to lowest insolation level also witnessed in this month because increased water content in the atmosphere gives rise to cloudy weather and scattering of sun's rays. Other factors being equal, high relative humidity brings about low module temperature which would normally favour open-circuit voltage more than short-circuit current, but with such very high value of relative humidity as recorded in August, its effect becomes domineering and results in very low insolation level that dictates the results of other parameters as is shown in the Table, and that explains the lowest recorded values of all the per- 
formance variables for the monocrystalline, polycrystalline as well as amorphous silicon modules.

The performances of the three photovoltaic modules at different levels of solar irradiance (global irradiance) for the period studied were summarised in Table 5. Fill factor and efficiency at the different levels of irradiance for the modules were also computed and inserted.

Table 4: Monthly average values of global irradiance, wind speed, relative hmidity and module temperature with the performance variables

\begin{tabular}{|c|c|c|c|c|c|c|c|c|c|c|c|c|c|c|c|}
\hline \multirow[t]{2}{*}{ Month } & \multirow{2}{*}{$\begin{array}{c}\mathrm{H}_{\mathrm{B}} \\
\left(\mathrm{W} / \mathrm{m}^{2}\right)\end{array}$} & \multirow{2}{*}{$\begin{array}{c}\text { WS } \\
(\mathrm{m} / \mathrm{s})\end{array}$} & \multirow{2}{*}{$\begin{array}{l}\text { RH } \\
(\%)\end{array}$} & \multicolumn{4}{|c|}{ Monocrystalline } & \multicolumn{4}{|c|}{ Polycrystalline } & \multicolumn{4}{|c|}{ Amorphous } \\
\hline & & & & $V_{o c}(V)$ & $I_{x}(A)$ & $P_{\text {m }}(W)$ & $T_{\text {mod }}\left({ }^{\circ} \mathrm{C}\right)$ & $V_{\alpha}(V)$ & $\mathrm{L}_{\mathrm{sc}}(\mathrm{A})$ & $P_{\text {min }}(W)$ & $\mathrm{T}_{\text {mod }}\left({ }^{\circ} \mathrm{C}\right)$ & $V_{o c}(V)$ & $\mathrm{I}_{\mathrm{sc}}(\mathrm{A})$ & $P_{\mathbf{m}}(W)$ & $\mathrm{T}_{\bmod }\left({ }^{\circ} \mathrm{C}\right)$ \\
\hline Dec 14 & 509.5 & 1.68 & 32.08 & 4.621 & 0.088 & 0.343 & 38.01 & 5.880 & 0.146 & 0.699 & 35.14 & 4.707 & 0.046 & 0243 & 3626 \\
\hline Jan 15 & 529.8 & 1.99 & 25.97 & 4.620 & 0.091 & 0.352 & 36.54 & 5.919 & 0.147 & 0.721 & 33.63 & 4.146 & 0.045 & 0214 & 34.41 \\
\hline Feb 15 & 529.6 & 1.59 & 32.06 & 4282 & 0.085 & 0.311 & 41.66 & 5.693 & 0.139 & 0.656 & 3922 & 3.447 & 0.043 & 0.178 & 37.95 \\
\hline Mar 15 & 537.6 & 1.88 & 33.14 & 4272 & 0.084 & 0.311 & 41.57 & 5.761 & 0.140 & 0.670 & 39.49 & 2.664 & 0.040 & 0.138 & 38.18 \\
\hline Apr 15 & 569.0 & 1.70 & 31.99 & 4.683 & 0.095 & 0.354 & 42.96 & 6211 & 0.157 & 0.779 & 40.54 & 2.201 & 0.040 & 0.114 & 39.52 \\
\hline May 15 & 509.9 & 1.81 & 55.87 & 4.499 & 0.085 & 0.319 & 38.54 & 6301 & 0.151 & 0.747 & 37.71 & 2.408 & 0.040 & 0.124 & 3633 \\
\hline Jun 15 & 424.3 & 1.74 & 71.40 & 3.695 & 0.069 & 0.244 & 34.33 & 5.596 & 0.125 & 0.587 & 33.03 & 1.447 & 0.032 & 0.075 & 32.10 \\
\hline Jul 15 & 415.7 & 1.68 & 73.14 & 3.533 & 0.070 & 0.243 & 34.29 & 5.555 & 0.124 & 0.573 & 32.52 & 1.587 & 0.032 & 0.082 & 31.45 \\
\hline Aug 15 & 326.4 & 1.45 & 81.08 & 3.020 & 0.060 & 0.195 & 31.90 & 4292 & 0.086 & 0.379 & 30.42 & 0.944 & 0.028 & 0.049 & 2932 \\
\hline Sep 15 & 415.8 & 1.47 & 74.15 & 3.936 & 0.080 & 0.283 & 35.42 & 5.174 & 0.128 & 0.627 & 3321 & 2.195 & 0.037 & 0.113 & 31.60 \\
\hline Oct 15 & 479.9 & 139 & 70.18 & 4.621 & 0.097 & 0.358 & 38.96 & 6.071 & 0.153 & 0.761 & 35.75 & 3.697 & 0.046 & 0.191 & 33.88 \\
\hline Nov 15 & 557.9 & 1.41 & 35.34 & 5.144 & 0.116 & 0.441 & 42.48 & 6250 & 0.176 & 0.893 & 38.00 & 6.085 & 0.055 & 0314 & 36.98 \\
\hline
\end{tabular}

Table 5: Summary of perfomance response for the three modales at dfferent imadance levels

\begin{tabular}{|c|c|c|c|c|c|c|c|c|c|c|c|c|c|c|c|c|c|c|c|c|c|}
\hline \multirow{2}{*}{$\begin{array}{l}\text { Irradiance } \\
\left(\mathrm{W} / \mathrm{m}^{2}\right)\end{array}$} & \multicolumn{7}{|c|}{ Monocrystalline Module } & \multicolumn{7}{|c|}{ Polycrystalline Module } & \multicolumn{7}{|c|}{ Amorphous Module } \\
\hline & $V_{\alpha}$ & $\mathrm{I}_{\mathrm{sc}}$ & $P_{\max }$ & $V_{\text {max }}$ & $\mathrm{L}_{\max }$ & FF & Eff( $\%)$ & $V_{\alpha}$ & $I_{s c}$ & $P_{\max }$ & $V_{\max }$ & $\mathrm{L}_{\max }$ & FF & Eff( $\%)$ & $V_{o c}$ & $I_{s c}$ & $P_{\max }$ & $V_{\max }$ & $\mathrm{L}_{\max }$ & FF & Eff( $\%)$ \\
\hline 276 & 6.12 & 0.083 & 0.311 & 6.12 & 0.051 & 0.615 & 524 & 6.83 & 0.131 & 0.624 & 6.439 & 0.097 & 0.698 & 10.64 & 0.03 & 0.035 & 0.001 & 0.025 & 0.036 & 1.029 & 0.01 \\
\hline 375 & 6.17 & 0.106 & 0.475 & 4.74 & 0.100 & 0.725 & 5.86 & 6.81 & 0.158 & 0.869 & 6.052 & 0.144 & 0.810 & 10.91 & 0.04 & 0.047 & 0.002 & 0.035 & 0.048 & 0.894 & 0.02 \\
\hline 437 & 634 & 0.119 & 0.523 & 533 & 0.098 & 0.693 & 555 & 6.90 & 0.190 & 0.921 & 6354 & 0.145 & 0.703 & 9.90 & 4.26 & 0.055 & 0222 & 4.261 & 0.052 & 0.946 & 1.76 \\
\hline 537 & 6.27 & 0.137 & 0.558 & 5.49 & 0.102 & 0.651 & 4.82 & 6.83 & 0205 & 1.113 & 5.892 & 0.189 & 0.795 & 9.74 & 10.98 & 0.065 & 0.558 & 10.980 & 0.051 & 0.785 & 3.61 \\
\hline 643 & 6.48 & 0.152 & 0.583 & 5.82 & 0.100 & 0.592 & 420 & 6.93 & 0231 & 1.196 & 6263 & 0.191 & 0.748 & 8.73 & 13.03 & 0.075 & 0.670 & 13.030 & 0.051 & 0.680 & 3.58 \\
\hline 743 & 631 & 0.167 & 0.663 & 4.51 & 0.147 & 0.629 & 4.13 & 6.81 & 0255 & 1394 & 5.847 & 0238 & 0.801 & 8.79 & 13.56 & 0.085 & 0.707 & 13.560 & 0.052 & 0.612 & 328 \\
\hline 835 & 629 & 0.173 & 0.694 & 4.68 & 0.148 & 0.638 & 3.85 & 6.74 & 0271 & 1.402 & 5.882 & 0238 & 0.767 & 7.87 & 13.76 & 0.091 & 0.718 & 13.760 & 0.052 & 0.571 & 297 \\
\hline 912 & 626 & 0.158 & 0.636 & 427 & 0.149 & 0.643 & 323 & 6.77 & 0249 & 1221 & 5224 & 0234 & 0.726 & 629 & 11.83 & 0.077 & 0.601 & 11.830 & 0.051 & 0.662 & 229 \\
\hline 933 & 6.48 & 0.147 & 0.578 & 5.81 & 0.100 & 0.609 & 2.88 & 7.03 & 0242 & 1222 & 6374 & 0.192 & 0.719 & 6.16 & 1229 & 0.079 & 0.641 & 12290 & 0.052 & 0.658 & 237 \\
\hline 1000 & 6.51 & 0.160 & 0.711 & 4.69 & 0.152 & 0.684 & 330 & 7.00 & 0255 & 1323 & 5.646 & 0234 & 0.741 & 620 & 12.50 & 0.080 & 0.652 & 12.500 & 0.052 & 0.650 & 225 \\
\hline & & & $P \max$ & $\begin{array}{l}\mathrm{T}_{\bmod }= \\
\text { MPR } \\
(\%)=\end{array}$ & $\begin{array}{l}5.34^{\circ} \mathrm{C} \\
0.07 \\
.11 \%\end{array}$ & & & \multicolumn{7}{|c|}{$\begin{array}{l}\mathrm{T}_{\mathbf{m i d}}=41.7^{\circ} \mathrm{C} \\
\mathrm{MPR}=0.13\end{array}$} & \multicolumn{7}{|c|}{$\begin{array}{l}\mathrm{T}_{\mathbf{m i d}}=37.7^{\circ} \mathrm{C} \\
\mathrm{MPR}=0.07\end{array}$} \\
\hline
\end{tabular}

For comparison between the modules performances and the STC specifications, module performance ratio (MPR), module temperature and maximum power at $1000 \mathrm{~W} / \mathrm{m}^{2}$ is equally presented. The maximum power output achieved for the modules at $1000 \mathrm{~W} / \mathrm{m}^{2}$ were $0.711 \mathrm{~W}, 1.323 \mathrm{~W}$ and $0.652 \mathrm{~W}$ representing $7.11 \%, 13.23$ $\%$ and $6.52 \%$ of the manufacturer's power specifications for the monocrystalline, polycrystalline and amorphous photovoltaic modules respectively. Module efficiency for the three module types are seen to decrease steadily as solar irradiance increased with maximum value of $5.86 \%$ and $10.91 \%$ for the monocrystalline and polycrystalline respectively recorded at irradiance of 375 $\mathrm{W} / \mathrm{m}^{2}$ while the amorphous efficiency peaked at irradiance of $536.5 \mathrm{~W} / \mathrm{m}^{2}$ with the value of $3.61 \%$. These maximum values then decreased steadily with increased irradiance and at 1000 $\mathrm{W} / \mathrm{m}^{2}$ the efficiency reduced to $3.30 \%, 6.20 \%$ and $2.25 \%$ as against manufacturer's specifications of $46 \%, 48 \%$ and $33 \%$ for the monocrystalline, polycrystalline and amorphous respectively. Open-circuit voltages at $1000 \mathrm{~W} / \mathrm{m}^{2}$ were $6.514 \mathrm{~V}, 6.996 \mathrm{~V}$ and $12.5 \mathrm{~V}$ as against manufacturer's specifications of $21.6 \mathrm{~V}, 21.6 \mathrm{~V}$ and $21.2 \mathrm{~V}$ for the monocrystalline, polycrystalline and amorphous respectively, while the short-circuit currents were $0.16 \mathrm{~A}$, $0.255 \mathrm{~A}$ and $0.80 \mathrm{~A}$ as against manufacturer's specifications of $0.65 \mathrm{~A}, 0.67 \mathrm{~A}$ and $0.62 \mathrm{~A}$ for the monocrystalline, polycrystalline and amorphous respectively. Maximum voltage, $\mathrm{V}_{\max }$, which according to the manufacturer's STC specification is $17.4 \mathrm{~V}$ each for the three modules, recorded $4.687 \mathrm{~V}, 5.646 \mathrm{~V}$ and $12.500 \mathrm{~V}$ at $1000 \mathrm{~W} / \mathrm{m}^{2}$ respectively, while maximum current, Imax recorded $0.152 \mathrm{~A}, 0.234 \mathrm{~A}$ and $0.052 \mathrm{~A}$ respectively for the monocrystalline, polycrystalline and amorphous, as against STC values of 0.57 A, 0.59 A and 0.55 A. Therefore, module performance ratios for these PV modules under investigation are $0.07,0.13$ and 0.07 for the monocrystalline, polycrystalline and amorphous respectively and it was equally observed here that none of these PV modules recorded module temperature of $25^{\circ} \mathrm{C}$ at $1000 \mathrm{~W} / \mathrm{m}^{2}$ solar irradiance as usually assumed for STC condition, rather, as seen in Table 5 , all recorded module temperatures are well beyond $25{ }^{\circ} \mathrm{C}$ in the local environment. It is then quite clear and obvious, given the enormous margin of deviation of the outdoor characterised values from the manufacturer's STC specifications, that STC data is suspect; it is only handy in making comparison among solar modules. Designing with manufacturer's STC data will produce an unreliable and defective PV power system. Judging from all indications, the polycrystalline module performed best in the Minna local environment. In addition, over specified modules are flooding our local market.

\subsection{Results of statistical analysis and models}

The prediction models for $\mathrm{V}_{\mathrm{oc}}, \mathrm{I}_{\mathrm{sc}}, \mathrm{P}$ and $\mathrm{P}_{\max }$ at different levels of irradiance and module temperature for the performance variables resulting from this work are all good, judging by statistical index, and are as follows:

Monocrystalline

$$
\begin{aligned}
& \mathrm{V}_{\mathrm{oc}}=-3.40+0.00672 \mathrm{H}_{\mathrm{g}}+0.115 \mathrm{~T}_{\mathrm{mod}} \\
& \mathrm{I}_{\mathrm{sc}}=-0.0616+0.000115 \mathrm{H}_{\mathrm{g}}+0.00233 \mathrm{~T}_{\mathrm{mod}} \\
& \mathrm{P}=-0.156+0.000320 \mathrm{H}_{\mathrm{g}}+0.00577 \mathrm{~T}_{\text {mod }}
\end{aligned}
$$


$P_{\max }=-0.389+0.000579 \mathrm{Hg}+0.0110 \mathrm{Tmod}$

Polycrystalline

$\mathrm{V}_{\mathrm{oc}}=1.11+0.00564 \mathrm{H}_{\mathrm{g}}+0.0523 \mathrm{~T}_{\bmod }$

$\mathrm{I}_{\mathrm{sc}}=-0.0759+0.000219 \mathrm{H}_{\mathrm{g}}+0.00298 \mathrm{~T}_{\bmod }$

$\mathrm{P}=0.106+0.000258 \mathrm{Hg}_{\mathrm{g}}+0.00156 \mathrm{~T}_{\mathrm{mod}}$

$\mathrm{P}_{\max }=-0.49019+0.00130 \mathrm{H}_{\mathrm{g}}+0.0151 \mathrm{~T}_{\bmod }$

Amorphous

$\mathrm{V}_{\mathrm{oc}}=-6.46+0.0109 \mathrm{H}_{\mathrm{g}}+0.110 \mathrm{~T}_{\mathrm{mod}}$
$\mathrm{I}_{\mathrm{sc}}=-0.0159+0.000072 \mathrm{H}_{\mathrm{g}}+0.000577 \mathrm{~T}_{\bmod }$

$\mathrm{P}=-0.316+0.000578 \mathrm{H}_{\mathrm{g}}+0.00515 \mathrm{~T}_{\bmod }$

$\mathrm{P}_{\max }=-0.324+0.000567 \mathrm{H}_{\mathrm{g}}+0.00542 \mathrm{~T}_{\bmod }$

\subsection{Comparison between measured and predicted per- formance variables}

For the purpose of comparison between measured and predicted data, the predicted performance variables at different levels of irradiance and module temperature were plotted with the measured variables and the result for short-circuit current is presented in Figures $28-30$ for the three module types.

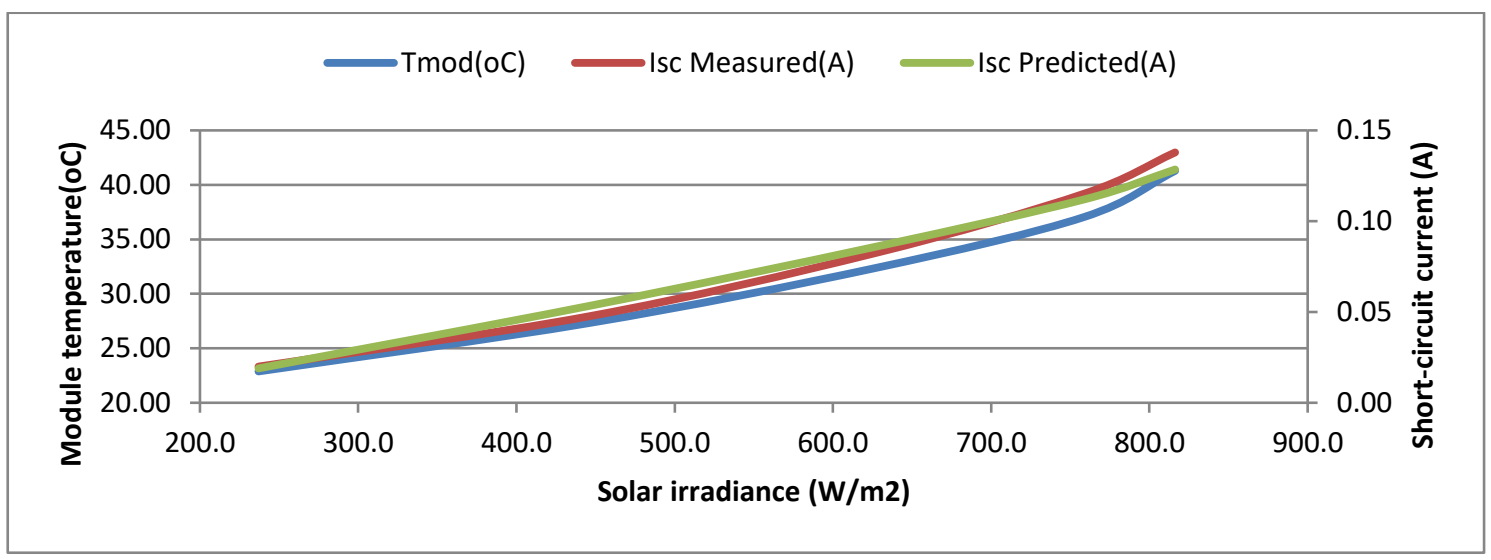

Fig. 28:Measured and Predicted Short-Circuit Current with Module Temperature as A Function of Solar Irradiance for the Monocrystalline Module.

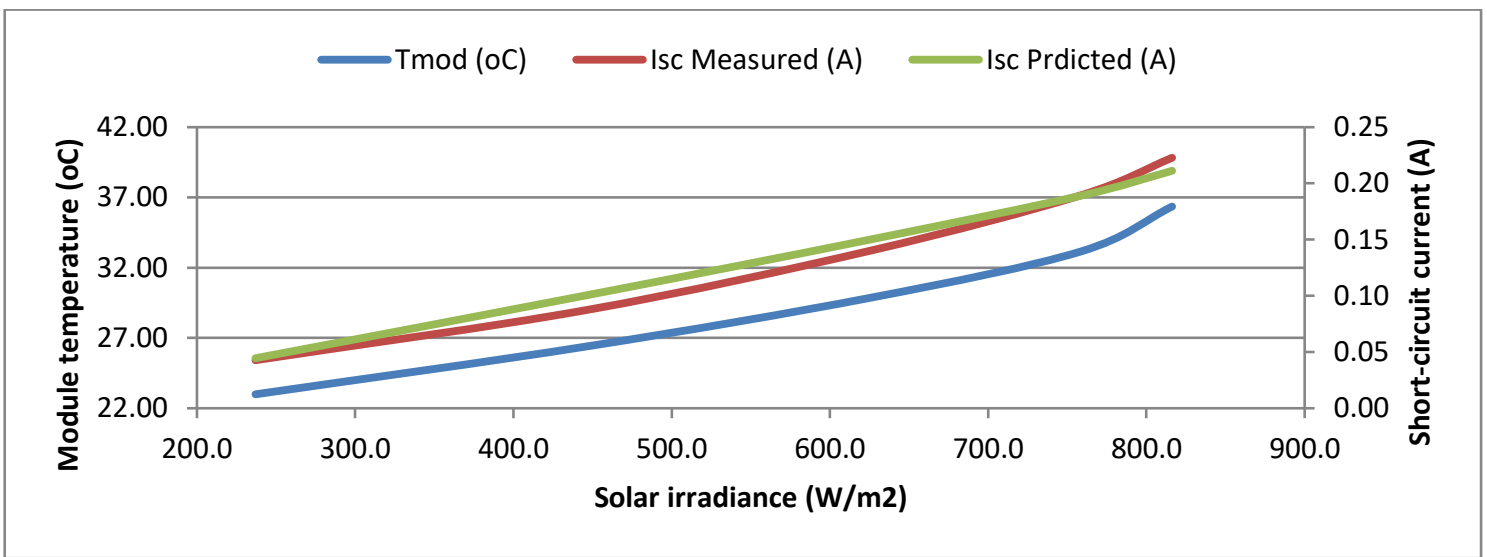

Fig. 29:Measured and Predicted Short-Circuit Current with Module Temperature as A Function of Solar Irradiance for the Polycrystalline Module.

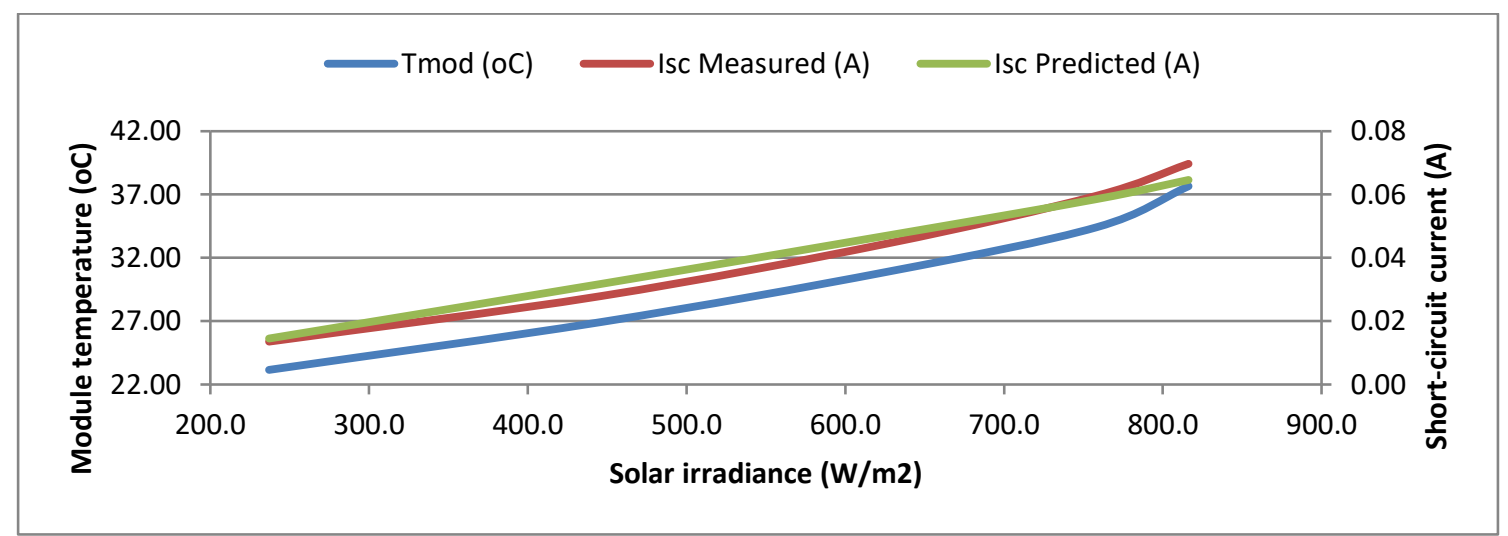

Fig. 30:Measured and Predicted Short-Circuit Current with Module Temperature as A Function of Solar Irradiance for the Amorphous Module.

\section{Conclusion}

The outdoor characterisation and performance evaluation of different types of photovoltaic modules in Minna local environment reveals that actual values of performance variables of the modules differ greatly from the manufacturer's specifications. The magnitude of the difference between STC specification and the realistic outdoor performance, in this particular study, points to the fact that over rated modules are entering our local market. The maxi- 
mum power output achieved for the modules at irradiance of 1000 $\mathrm{W} / \mathrm{m}^{2}$ were $0.711 \mathrm{~W}, 1.323 \mathrm{~W}$ and $0.652 \mathrm{~W}$ representing $7.11 \%$, $13.23 \%$ and $6.52 \%$ of the manufacturer's power specifications for the monocrystalline, polycrystalline and amorphous photovoltaic modules respectively. While module efficiency for the three module types peaked at irradiance of $375 \mathrm{~W} / \mathrm{m}^{2}$ with the values of $5.86 \%$ and $10.91 \%$ for the monocrystalline and polycrystalline respectively, and the amorphous efficiency peaked at irradiance of $536.5 \mathrm{~W} / \mathrm{m}^{2}$ with the value of $3.61 \%$. These maximum values then decreased steadily with increased irradiance and at 1000 $\mathrm{W} / \mathrm{m}^{2}$ the efficiency reduced to $3.30 \%, 6.20 \%$ and $2.25 \%$ as against manufacturer's specifications of $46 \%, 48 \%$ and $33 \%$ for the monocrystalline, polycrystalline and amorphous respectively. Similarly, it was observed that the modules did not record $25^{\circ} \mathrm{C}$ module temperature at irradiance of $1000 \mathrm{~W} / \mathrm{m}^{2}$ as used in STC specifications by the manufacturer. Module temperature was therefore observed to have significant influence on the general performances of the modules. In addition to the temperature effects on the performance of the module, some non-intrinsic effects like module mismatch, dust and ohmic losses can contribute to some fraction of the observed reduction in output performances [8] [11].

It is recommended that outdoor characterisation and performance evaluation of all commercially available PV modules be carried out in every location of developing countries where this is lacking. Results should be collated, adopted and installers of PV power systems made to abide by the regulations thereof to ensure technical quality. Also government should put adequate mechanism in place to checkmate over rated PV modules and dumping.

\section{References}

[1] F. Almonacid, C. Rus, L. Hontoria, M. Fuentes and G. Nofuentes, (2009). Characterisation of Si-Crystalline PV Modules by Artificial Neural Networks, Journal of Renewable Energy, 34 (4) 941-949; www.elsevier.com/locate/renene https://doi.org/10.1016/j.renene.2008.06.010.

[2] California Energy Commission: Energy Development Division (2001). A Guide to PV System Design and Installation, California, USA; www.energy.ca.gov/reports/2001-09-04_500-01-020.PDF

[3] I.H. Umar (1999). Research and Development and Energy Crisis in Nigeria. Proceedings of 1999 Technology Summit, Abuja, Nigeria, pp 39-42.

[4] E.N.C. Okafor\& C.K.A. Joe-Uzuegbu, (2010). Challenges to Development of Renewable Energy for Electric Power Sector in Nigeria. International Journal of Academic Research, 2 (2), 211-216; URL: www.ijar.lit.az

[5] Midwest Renewable Energy Association Fact Sheet: Off Grid PV Systems (2013).www.doe.erec@nciinc.com, (accessed 13.05.13).

[6] S.J. Strong \& W.G. Scheller, (1991). The Photovoltiac Room. $2^{\text {nd }}$ ed. Sustainability Press, Massachusetts.

[7] P.E. Ugwuoke, F.I. Ezema\& C.E. Okeke (2005). Performance Response of Monocrystalline PV Modules to Some Meteorological Parameters at Nsukka, Nigerian Journal of Space Research, 3 (2), 63-69.

[8] P.E. Ugwuoke\& C.E. Okeke, (2012). Performance Assessment of Three Different PV Modules as a Function of Solar Insolation in South Eastern Nigeria, International Journal of Applied Science and Technology, 2 (3), 319-327; www.ijastnet.com

[9] S.C. Bajpai\& R.C. Gupta, (1986). Effects of Temperature Variations on the Performance of Monocrystalline Solar Cells. Nigerian Journal of Solar Energy, 5, 35-41.

[10] P.E. Ugwuoke, (2005). Characterisation and Performance Evaluation of Crystalline and Amorphous Photovoltaic Modules in Nsukka under Field Conditions. PhD Thesis, Department of Physics and Astronomy, University of Nigeria, Nsukka.

[11] S. Causi Li, C. Messana, G. Noviella, A. Paretta \& A. Sarno, (1995). Performance Analysis of Single Crystal Silicon Modules in Real Operating Conditions. Proceedings of $13^{\text {th }}$ European Photovoltaic Solar Energy Conference Nice, France, pp 11-14; https://www.eupvsec-proceedings.com/proceedings?offset=60. 